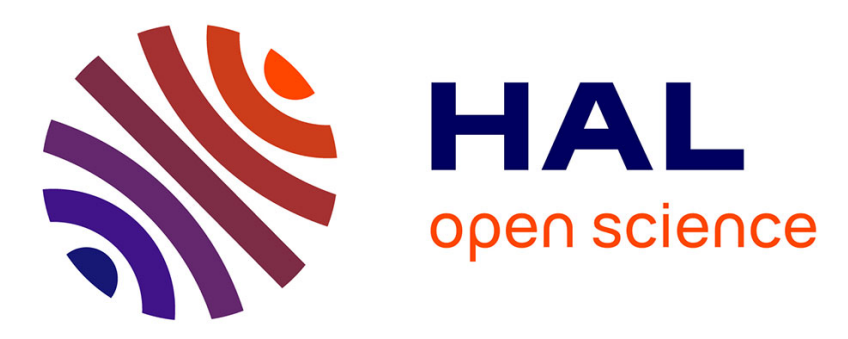

\title{
Simulation of atmospheric CO2 over Europe and western Siberia using the regional scale model REMO
}

Anne Chevillard, Ute Karstens, Philippe Ciais, Sébastien Lafont, Martin Heimann

\section{- To cite this version:}

Anne Chevillard, Ute Karstens, Philippe Ciais, Sébastien Lafont, Martin Heimann. Simulation of atmospheric CO2 over Europe and western Siberia using the regional scale model REMO. Tellus B

- Chemical and Physical Meteorology, 2002, 54 (5), pp.872-894. 10.1034/j.1600-0889.2002.01340.x . hal-02923935

\section{HAL Id: hal-02923935 \\ https://hal.science/hal-02923935}

Submitted on 29 Oct 2020

HAL is a multi-disciplinary open access archive for the deposit and dissemination of scientific research documents, whether they are published or not. The documents may come from teaching and research institutions in France or abroad, or from public or private research centers.
L'archive ouverte pluridisciplinaire HAL, est destinée au dépôt et à la diffusion de documents scientifiques de niveau recherche, publiés ou non, émanant des établissements d'enseignement et de recherche français ou étrangers, des laboratoires publics ou privés. 


\section{Tellus B: Chemical and Physical Meteorology}

\section{Simulation of atmospheric $\mathrm{CO}_{2}$ over Europe and western Siberia using the regional scale model REMO}

\section{Anne Chevillard, Ute Karstens, Philippe Ciais, Sébastien Lafont \& Martin Heimann}

To cite this article: Anne Chevillard, Ute Karstens, Philippe Ciais, Sébastien Lafont \& Martin Heimann (2002) Simulation of atmospheric $\mathrm{CO}_{2}$ over Europe and western Siberia using the regional scale model REMO, Tellus B: Chemical and Physical Meteorology, 54:5, 872-894, DOI: 10.3402/tellusb.v54i5.16737

To link to this article: https://doi.org/10.3402/tellusb.v54i5.16737

$$
\begin{aligned}
& \text { (c) } 2002 \text { The Author(s). Published by Taylor \& } \\
& \text { Francis. }
\end{aligned}
$$

\section{曲 Published online: 15 Dec 2016.}

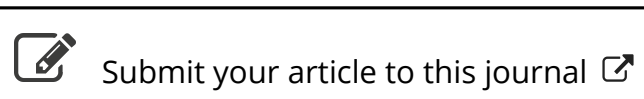

\section{Џll Article views: 52}

Q View related articles 둔

7 Citing articles: 11 View citing articles 


\title{
Simulation of atmospheric $\mathrm{CO}_{2}$ over Europe and western Siberia using the regional scale model REMO
}

\author{
By ANNE CHEVILLARD ${ }^{1 *}$, UTE KARSTENS ${ }^{2}$, PHILIPPE CIAIS ${ }^{1}$, SÉBASTIEN LAFONT ${ }^{3}$ and MARTIN \\ HEIMANN ${ }^{2},{ }^{1}$ Laboratoire des Sciences du Climat et de l'Environnement, UMR CEA-CNRS 1572, F-91198 \\ Gif-sur-Yvette, France; ${ }^{2}$ Max-Planck-Institut für Biogeochemie, D-07701 Jena, Germany; ${ }^{3}$ CESBIO, UMR \\ CNRS-CNES-UPS, 18 av. E. Belin, Toulouse, France
}

(Manuscript received 9 July 2001; in final form 13 June 2002)

\begin{abstract}
The spatial distribution and the temporal variability of atmospheric $\mathrm{CO}_{2}$ over Europe and western Siberia are investigated using the regional atmospheric model, REMO. The model, of typical horizontal resolution $50 \mathrm{~km}$, is part of a nested modelling framework that has been established as a concerted action during the EUROSIBERIAN CARBONFLUX project. In REMO, the transport of $\mathrm{CO}_{2}$ is simulated together with climate variables, which offers the possibility of calculating at each time step the land atmosphere $\mathrm{CO}_{2}$ fluxes as driven by the modelled meteorology. The uptake of $\mathrm{CO}_{2}$ by photosynthesis is calculated using a light use efficiency formulation, where the absorbed photosynthetically active solar radiation is inferred from satellite measurements. The release of $\mathrm{CO}_{2}$ from plant and soil respiration is driven by the simulated climate and assumed to be in equilibrium with photosynthesis over the course of one year. Fossil $\mathrm{CO}_{2}$ emissions and air-sea fluxes within the model domain are prescribed, whereas the influence of sources outside the model domain is computed from as a boundary condition $\mathrm{CO}_{2}$ fields determined a global transport model. The modelling results are compared against pointwise eddy covariance fluxes, and against atmospheric $\mathrm{CO}_{2}$ records. We show that a necessary condition to simulate realistically the variability of atmospheric $\mathrm{CO}_{2}$ over continental Europe is to account for the diurnal cycle of biospheric exchange. Overall, for the study period of July 1998, REMO realistically simulates the short-term variability of fluxes and of atmospheric mixing ratios. However, the mean $\mathrm{CO}_{2}$ gradients from western Europe to western Siberia are not correctly reproduced. This latter deficiency points out the key role of boundary conditions in a limited-area model, as well as the need for using more realistic geographic mean patterns of biospheric carbon fluxes.
\end{abstract}

\section{Introduction}

The spatial and temporal distribution and variability of $\mathrm{CO}_{2}$ are still poorly known over large parts of the globe. In the framework of the EUROSIBERIAN CARBONFLUX project the possibilities of inferring regional carbon fluxes over Europe and western Siberia from a combination of $\mathrm{CO}_{2}$ measurements and

${ }^{*}$ Corresponding author.

e-mail: anne.chevillard@irsn.fr

Present affiliation: Institut de Radioprotection et de Sûreté Nucléaire, DPRE/SERGD/LEIRPA, B.P. 17, F-92262 Fontenay-aux-Roses, France. modelling efforts on different scales are investigated. For a long-lived trace gas like $\mathrm{CO}_{2}$ the spatial distribution and temporal variation depends on the patterns of sources and sinks as well as on local and largescale transport. To describe adequately all processes involved, a hierarchy of models, from global down to local scales, would be necessary. In this study we focus on the intermediate scale, using a regional mesoscale model of limited area, which covers most of the Eurosiberian continent $\left(36 \times 10^{6} \mathrm{~km}^{2}\right)$. Our model has a horizontal resolution on the order of $20-60 \mathrm{~km}$ and can resolve the heterogeneity of the surface and the meteorological processes in much greater detail than most present-day coarser global models. In order to run the 
limited area model, the large-scale meteorology has to be specified at boundaries and initial conditions, here taken from weather forecast analyses. Boundary conditions for tracers must be specified, and we prescribe them from the output of the global coarse-grid TM3 model.

Atmospheric transport of tracers can either be performed "on-line" as part of the atmospheric model which calculates the meteorology, or "off-line" by reading meteorological fields from analyses and recomputing subgrid scale processes. While the latter approach is less time-consuming and therefore widely used on global (Heimann, 1995; Ciais et al., 1997) and regional scales (e.g. Engardt and Holmén, 1999; Kjellström et al., 2002), the "on-line" transport modelling offers the possibility to couple consistently atmospheric transport and meteorology-driven biospheric sources (e.g. Denning et al., 1996). This gives access to the temporal variability of the meteorological fields at the time-step level, and thus allows us to compute biospheric fluxes at a fine inner day resolution.

In this study, we use the on-line regional scale atmospheric model REMO to simulate the transport of $\mathrm{CO}_{2}$ in Europe and western Siberia. The modelling framework is described in Fig. 1. The model (two versions) is briefly described in section 2 . In section 3 , the sources and sinks of $\mathrm{CO}_{2}$ which are used in the simulations, as well as boundary and initial conditions, are described. Special attention in given to net ecosystem exchange flux (NEE), driven by the model meteorology and satellite observations. The simulated NEE is compared with eddy covariance flux tower measurements. In section 4, the results of the simulations are discussed for July 1998, and a more detailed comparison with atmospheric measurements is given in section 5. We selected measurements at 13 atmospheric stations, two short towers of flux measurements and two aircraft intensive sets of vertical profiles.

\section{Model description}

The REgional MOdel REMO is based on the Europamodell (EM) of the German Weather Service (DWD) (Majewski, 1991). For almost 10 years the Europamodell has been the operational regional weather forecast model of DWD. REMO has the possibility of using either the physical parameterisation package of EM or the same physics as the global climate model ECHAM-4 (Roeckner et al., 1996). Some sensitivity studies in different climatic regions were presented in Jacob and Podzun (1997).

The version of REMO (version 4.3) used in this study includes the DWD physical parameterisation package. The model uses the hydrostatic approximation with 20 vertical levels in a hybrid coordinate system with six layers below $1500 \mathrm{~m}$. The horizontal resolution is $0.5^{\circ}$ in a rotated spherical coordinate system, with the equator almost in the centre of the computational domain. This results in a horizontal grid size of roughly $55 \mathrm{~km} \times 55 \mathrm{~km}$. In the present study the model domain encompasses Europe and western Siberia

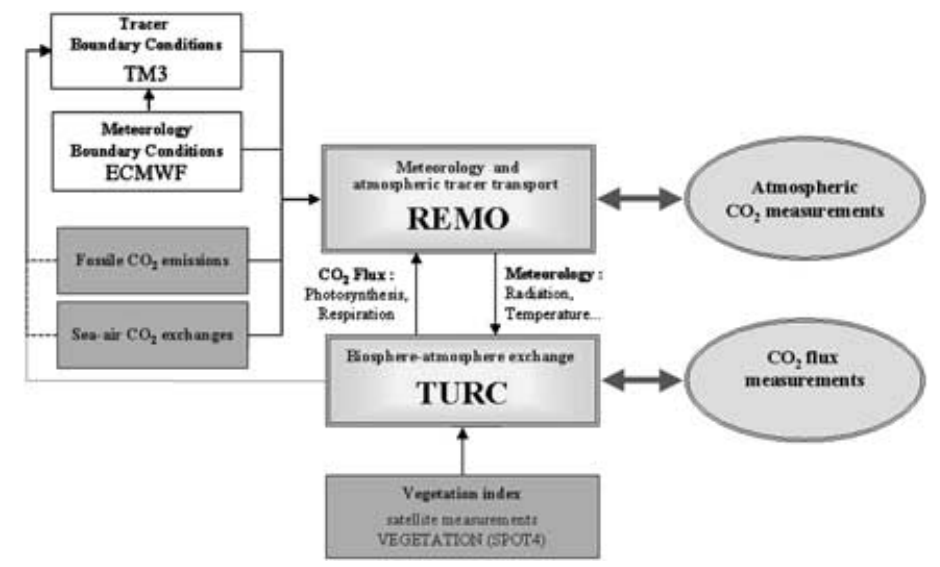

Fig. 1. Modelling framework to simulate biospheric fluxes and atmospheric $\mathrm{CO}_{2}$ mixing ratios with the regional-scale model REMO. The modelled Net Ecosystem Exchange is compared with pointwise eddy covariance data, whereas the modelled $\mathrm{CO}_{2}$ distribution is compared with atmospheric stations.

Tellus 54B (2002), 5 


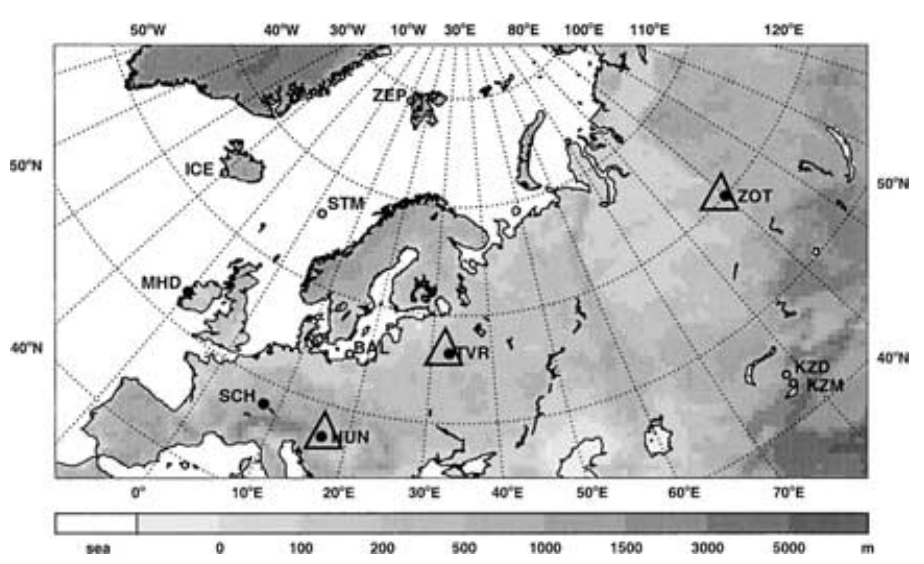

Fig. 2. The REMO model domain together with the sites used for the model-data comparison. Filled circles indicate continuous atmospheric $\mathrm{CO}_{2}$ records, open circles flask sampling stations and triangles eddy covariance sites used in this study.

(Fig. 2) and covers an area of $36 \times 10^{6} \mathrm{~km}^{2}$. Analyses of the European Centre for Medium-Range Weather Forecasts (ECMWF) are used as initial and boundary conditions for the meteorological part of the model. These boundary data are updated every $6 \mathrm{~h}$.

The performance of REMO in simulating the atmospheric circulation on the regional scale has been investigated in several studies by comparing model results to different types of measurements. Most of the comparisons have been focused on water and energy budget components and related parameters (Karstens et al., 1996; Ahrens et al., 1998; Hollmann et al., 2000; Lindau, 2000; Hamelbeck et al., 2001; Jacob et al., 2001; Jürrens, 1999; Meijgaard et al., 2001; Rockel and Karstens, 2001; Zhang et al., 2001). The comparison studies all showed that REMO is capable of realistically simulating synoptic and subsynoptic features. They also give an impression of the uncertainties involved in atmospheric modelling and reveal specific differences between model results and observations, leading to further model development efforts. Because the meteorological part of REMO in the version used in this study is very close to the EM we can also rely on the continuous verification efforts of DWD (Schrodin, 1993-1999).

The model was extended to an on-line atmospherechemistry model by implementing modules for the transport of tracers and tropospheric chemical processes (Langmann, 2000). In REMO the tracer transport is represented by horizontal and vertical advection, vertical diffusion and convective transport. Advective transport is solved explicitly according to the algorithm of Smolarkiewicz (1983). Subgridscale vertical turbulent fluxes are calculated following Louis (1979) in the surface layer and using a second order closure scheme (Mellor and Yamada, 1974) in the layers above. Vertical transport of tracers in convective clouds is parameterised in the same way as the transport of liquid water in the mass flux scheme by Tiedtke (1989). Tracer transport is calculated at every time step of the meteorology computation in the model.

In general, REMO can be operated in two different modes. In the "climate mode" (Jacob and Podzun, 1997) the model is initialised once and continuously forced at the lateral boundaries using either results obtained from a global climate model or analyses. In the "forecast mode" (Karstens et al., 1996), the results of consecutive short-range forecasts $(30 \mathrm{hs})$ are used. REMO is started for each day at 00 UTC from weather forecast analyses and a 30-hour forecast is computed. To account for a spin-up time the first six hours of the forecast are neglected. This spin-up time has been shown to be sufficient for EM of DWD and is therefore assumed adequate also in the present study. By restarting the model every day from analyses, the model state is forced to stay close to the weather situation of these analyses. The tracer transport is calculated continuously like in the "climate mode". This is done by simulating only the meteorology in the first 6 hours of each run and passing the tracer fields directly from the last time step of the previous 30-hour forecast.

In previous tracer transport studies (e.g. Langmann, 2000), which were focused on short episodes (several weeks), REMO was used in the forecast mode. However, the atmospheric transport of $\mathrm{CO}_{2}$ should be studied on longer periods (several months to several years). 
Table 1. Correlation coefficient between simulated and observed air temperature using two versions of REMO

\begin{tabular}{lcc}
\hline & $\begin{array}{c}\text { REMO forecast } \\
\text { observations }\end{array}$ & $\begin{array}{c}\text { REMO climate } \\
\text { observations }\end{array}$ \\
\hline SCH - 30 m & 0.91 & 0.61 \\
SCH - 130 m & 0.93 & 0.63 \\
TVR - forest & 0.66 & 0.48 \\
TVR - bog & 0.81 & 0.56 \\
ZOT - forest & 0.84 & 0.44 \\
ZOT - bog & 0.77 & 0.47 \\
\hline
\end{tabular}

We will therefore also investigate the performance of the model in the climate mode, which is computationally more efficient. In future scenario simulations, for instance to regionalise the impacts of climate change given by a global climate model output, the climate mode is more adapted.

Over the whole domain, the air temperature in July 1998 computed by the forecast mode is closer to the ECMWF analysis than the result of the climate mode. In the lowest level, the spatial average of the REMO minus ECMWF difference reaches $0.5 \pm 2.3^{\circ} \mathrm{C}$ in the climate mode, whereas it is only $-0.05 \pm 0.9^{\circ} \mathrm{C}$ in the forecast mode. The comparison of the observed and simulated temperature time series at several stations shows a better correlation for the forecast mode (Table 1). The correlation coefficient between model and observations for the forecast mode is between 0.66 and 0.93 , whereas it is only between 0.44 and 0.63 for the climate mode.

In the following analysis of $\mathrm{CO}_{2}$, we will therefore present mainly the results of the forecast mode. In the comparison with measurements, we will, however, also include the result of the climate mode (as well as the global model TM3), in order to quantify the effect of different atmospheric transport and meteorology on the $\mathrm{CO}_{2}$ mixing ratio. The differences between both modes are also discussed in section 4.4 .

\section{Model set-up for the fluxes and transport of $\mathrm{CO}_{2}$}

In order to analyse the effects of distinct sources that influence the $\mathrm{CO}_{2}$ distribution, we transported separately the different components (biospheric, oceanic and anthropogenic) produced by sources inside the REMO domain and by external sources, which pene-
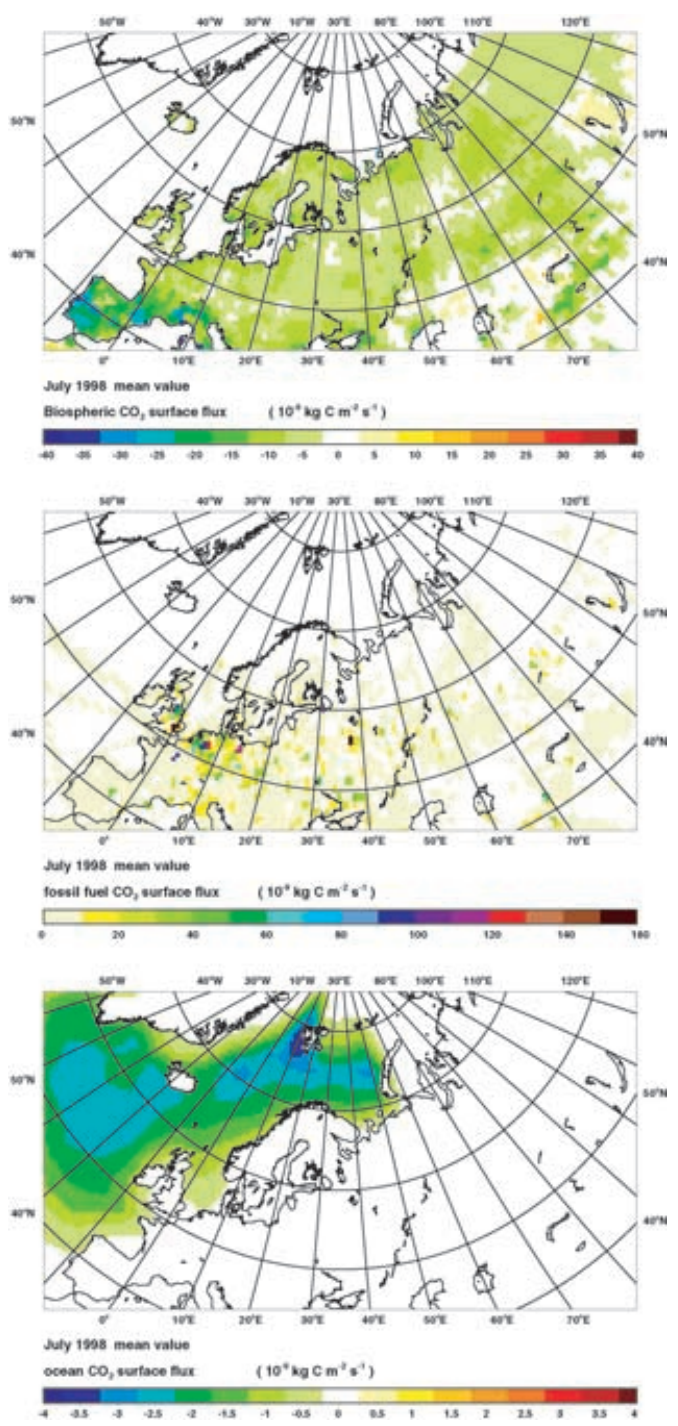

Fig. 3. Monthly fluxes in July 1998: net ecosystem exchange (NEE, upper panel), fossil fuel emissions (middle panel ) and net sea-air fluxes (lower panel). Units are $10^{-9} \mathrm{kgC} \mathrm{m}^{-2} \mathrm{~s}^{-1}$.

trate into the domain through the lateral boundaries, as summarised in Fig. 1. Figure 3 shows the July 1998 monthly means of the biospheric, oceanic and fossil fluxes. The monthly mean biospheric flux in the REMO domain is estimated from the TURC model to be a net sink of $-0.35 \mathrm{GtC}$ in July 1998. The net uptake of $\mathrm{CO}_{2}$ by the ocean within the model area is $-0.05 \mathrm{GtC}$, and the total fossil emission is $0.17 \mathrm{GtC}$. 


\subsection{Vegetation-atmosphere exchanges (NEE)}

The vegetation-atmosphere exchange of $\mathrm{CO}_{2}$ is described by the TURC model, Terrestrial Uptake and Release of Carbon (Lafont et al., 2002; Ruimy et al., 1996). The TURC model estimates carbon uptake (photosynthesis) and release by vegetation and soil (respiration) from meteorological variables and satellite observations. Plant photosynthesis, or Gross Primary Production (GPP), is set to be in balance with the sum of plant respiration for growth and maintenance, and soil heterotrophic respiration over one year. The net biospheric flux (NEE), positive when $\mathrm{CO}_{2}$ is released into the atmosphere, is the sum of all respiration terms minus photosynthesis. Photosynthesis depends on (1) Rad, incident solar global radiation, (2) $c$, the estimated fraction of $\mathrm{Rad}$ to be photosynthetically active, i.e. PAR ( $c=45.6 \%)$, (3) $f$, the absorption coefficient of the canopy, a linear function of the NDVI (Normalised Difference Vegetation Index) computed from satellite observations of VEGETATION, a SPOT4 spaceborne instrument, (4) $\varepsilon$, the photosynthetic efficiency, ratio of canopy photosynthesis to the absorbed radiation and (5) $g$, a "freezing factor" that divides by two the GPP when daily average air temperature is lower than $-2{ }^{\circ} \mathrm{C}$ during more than three consecutive days (Lafont et al., 2002).

$G P P=A \times \operatorname{Rad}$

where $A=g \times \varepsilon \times f \times c$ is a daily coefficient. Autotrophic respiration is separated into growth $(R A g)$ and maintenance fluxes $(R A m)$. RAm depends linearly on the ambient air temperature [eq. (2)]:

$R A m=A^{\prime} \times T_{\text {air }}+B^{\prime}$

where $A^{\prime}$ and $B^{\prime}$ are daily functions of plant biomass. If daily GPP is larger than daily $R A m$, the remaining assimilates are used by plants for growth respiration [eq. (3)]. The coefficient $D\left(=0.28 \mathrm{~g} \mathrm{~g}^{-1}\right)$ corresponds to the amount of glucose used to produce $1 \mathrm{~g}$ of dry matter (see Ruimy et al. (1996) for more details):

$R A g=D \times(G P P-R A m)_{\text {daily mean }}$.

The heterotrophic respiration $(R H)$ is related to the deviation of the soil temperature $\left(T_{\text {soil }}\right)$ from the reference temperature of $0{ }^{\circ} \mathrm{C}\left(T_{0}\right)$, according to a $Q_{10}$ exponential relationship $\left(Q_{10}=2\right)$. The coefficient $V_{0}$ in eq. (4) permits to decrease RH in wet soils and it is adjusted to equilibrate the net biospheric flux on an annual basis, which nevertheless restricts out analysis to seasonal or shorter time scales:
$R H=V_{0} \times Q 10^{\left(\frac{T s o i l-T 0}{10}\right)}$

In this study we use two methods to obtain hourly fluxes from the daily estimations of TURC. In REMO climate mode, daily $A, A^{\prime}, B^{\prime}, V_{0}$ and $R A g$ are provided by Lafont et al. (2002). One preliminary run of REMO, without tracer transport, is performed to drive TURC with the meteorological data necessary for the determination of $V_{0}$ and $R A g$. The fluxes are then determined simultaneously with atmospheric $\mathrm{CO}_{2}$ transport in REMO, according to eqs. (1)-(4), using REMO meteorological fields at each time step (5 min). In REMO forecast mode, the diurnal variations of $G P P, R A m$ and $R H$ are parameterised according to the eqs. (1), (2) and (4). As this mode is strongly constrained by the ECMWF fields, daily mean biospheric $\mathrm{CO}_{2}$ fluxes are determined using information from ECMWF analyses. The same procedure is also used in the global TM3 simulation that provides $\mathrm{CO}_{2}$ boundary conditions to REMO (see section 3.2).

3.1.1. Sensitivity of NEE to the photosynthetic efficiency. We tested two sets of $\varepsilon$ within the TURC model. The first set is from the original version of TURC by Ruimy et al. (1996), who used a uniform value of the $\varepsilon$ parameter $\left(0.020 \mathrm{~mol} \mathrm{CO}_{2}\right.$ per mol PAR). The second set is from Lafont et al. (2002), who suggest, based on a compilation of recently published eddy flux tower measurements, that the original $\varepsilon$ value is overestimated in bogs and boreal forests. The simulated NEE at Zotino (Central Siberia) is most affected by the lower $\varepsilon$ values recommended by Lafont et al., in contrast with the two other sites. Using lower $\varepsilon$ values greatly improved the TURC simulation there in July 1998, resulting in an important diminution (70\%) of the daily NEE amplitude, whereas the monthly mean $\mathrm{CO}_{2}$ sink is only reduced by $8 \%$. At Fyodorovskoye (European Russia), both the monthly biospheric sink and the daily NEE peak-to-peak amplitude are reduced by $30 \%$. At Hegyhátsál (Hungary), the monthly sink is doubled and the daily NEE amplitude stays constant. One can therefore anticipate that the atmospheric $\mathrm{CO}_{2}$ concentration is sensitive to decreasing the value of the $\varepsilon$ factor between Ruimy et al. (1996) and Lafont et al. (2002). On a monthly basis, the simulated average $\mathrm{CO}_{2}$ mixing ratio decreases at the lowest level (6 ppmv smaller at Zotino and about 1 ppmv at the two other sites), whereas it increases at $500 \mathrm{~m}$ above the ground. This is mainly due to the "rectification" coupling between daily variations of biospheric fluxes and daily variations of the vertical mixing. In the 
following, we only discuss results obtained with the $\varepsilon$ values of Lafont et al. (2002).

3.1.2. Comparison with NEE measured by eddy covariance. We checked the TURC fluxes driven by REMO forecast mode against eddy covariance measurements of NEE (Net Ecosystem Exchange) at three specific locations (See Appendix A1). The forecast mode is here preferred because it is closer to the observed meteorology on a day-to-day basis. Two eddy covariance systems were installed over forest and bog vegetation at Fyodorovskoye and Zotino as part of the EUROSIBERIAN CARBONFLUX project (Fig. 2). In addition, we used NEE data over a cropland/woodland mosaic at Hegyhátsál in Hungary because a precise atmospheric $\mathrm{CO}_{2}$ concentration record is also available at that site on top of a tall tower. Figure 4 compares the simulated NEE with eddy-flux measurements. The simulated NEE represent a composite average over the REMO grid cell which contains a flux tower site. However, some large differences exist in NEE between two towers within the same grid cell, located over different vegetation types, due to subgrid heterogeneity. For instance, at Fyodorovskoye over a southern taiga area, the correlation between the measured NEE over a 150-yr-old spruce stand and over a bog distant from few kilometres is of 0.66 only. At Zotino, the correlation between NEE of a 220 -yr-old pine forest stand and a bog nearby is of 0.69. Comparison between TURC driven by REMO and the eddy covariance NEE is therefore qualitative, but it can nevertheless provide a coarse check of the realism of the simulated fluxes, which is a prerequisite to obtain realistic atmospheric $\mathrm{CO}_{2}$ fields. In Figure 4 we observe a large difference in the daily peak-to-peak amplitude of

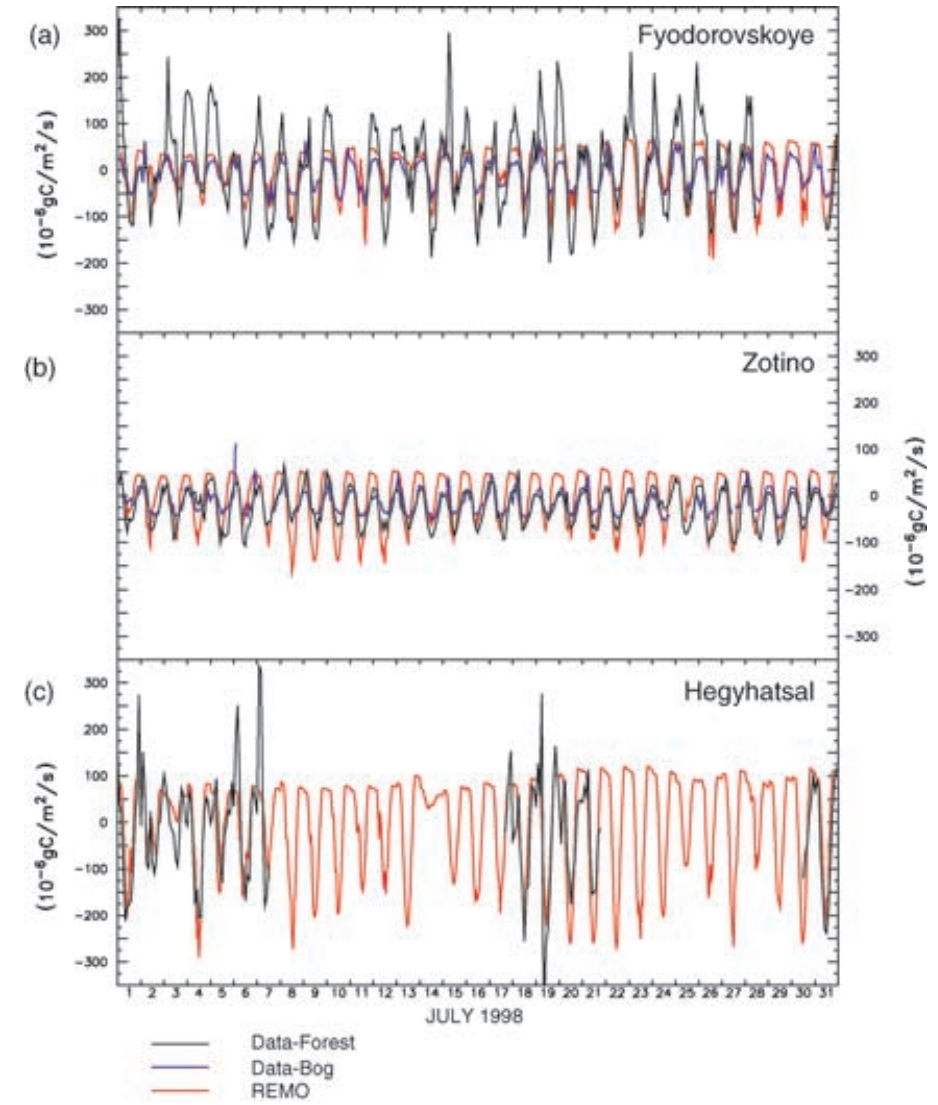

Fig. 4. Modelled (red) and observed (black) NEE along an East to West transect at Zotino (220-yr-old pine forest and nearby bog in central Siberia), Fyodorovskoye (150-yr-old spruce forest and nearby bog in European Russia) and Hegyhátsál (cropland and woodland mosaic in western Hungary).

Tellus 54B (2002), 5 
Table 2. Monthly mean peak-to-peak amplitude of $N E E\left(10^{-6} \mathrm{gC} \mathrm{m}^{-2} \mathrm{~s}^{-1}\right)^{\mathrm{a}}$

\begin{tabular}{lccc}
\hline NEE & REMO forecast & REMO climate & Observations \\
\hline HUN & $272.0 \pm 89.7$ & $280.4 \pm 93.7$ & $566.1 \pm 303.6$ \\
& $(0.61)$ & $(0.60)$ & \\
TVR & $145.1 \pm 48.0$ & $175.8 \pm 61.5$ & \\
Forest & $(0.71)$ & $(0.66)$ & $359.1 \pm 84.8$ \\
Bog & $(0.70)$ & $(0.64)$ & $135.3 \pm 55.5$ \\
ZOT & $150.1 \pm 32.0$ & $138.6 \pm 33.6$ & \\
Forest & $(0.76)$ & $(0.74)$ & $130.8 \pm 37.7$ \\
Bog & $(0.68)$ & $(0.66)$ & $101.4 \pm 43.7$ \\
\hline
\end{tabular}

${ }^{a}$ The correlation coefficient between model and observations is indicated in parenthesis.

the measured NEE between the three sites, with higher amplitude in Hegyhátsál $\left(566 \times 10^{-6} \mathrm{gC} \mathrm{m}^{-2} \mathrm{~s}^{-1}\right)$ and lower ones at Zotino $\left(131 \times 10^{-6} \mathrm{gC} \mathrm{m}^{-2} \mathrm{~s}^{-1}\right.$ in forest and $101 \times 10^{-6} \mathrm{gC} \mathrm{m}^{-2} \mathrm{~s}^{-1}$ in bog). The TURC model driven by REMO reproduces the variability of NEE on the East to West transect between Siberia, European Russia and Central Europe (Table 2). At Zotino, the modelled fluxes are of the same order of magnitude than the measured ones at the Pinus sylvestris site (correlation of 0.76 in Table 2). At Fyodorovskoye, the daytime simulated uptake matches reasonably well the spruce forest observations (correlation of 0.71 in Table 2), but the night-time simulated respiratory flux is lower than observed, and more comparable with measurements over the nearby bog. The measured respiration at the spruce site in Fyodorovskoye presents some nights (e.g. 19-20 and 23-28 July 1998) very large values as compared to the bog and to other days in forest (all flux data were corrected from storage terms using measured $\mathrm{CO}_{2}$ profiles within the canopy). The REMO model is not able to reproduce such "events" (they do not occur at the Zotino forest site). At Hegyhátsál, similarly, very large night-time respirations occasionally observed are not reproduced in TURC (correlation of 0.61 in Table 2), but the maximum daytime carbon uptake is well simulated by the model.

\subsection{Ocean-atmosphere fluxes and fossil fuel emissions}

The sea-to-air flux of $\mathrm{CO}_{2}$ is described according to Takahashi et al. (1999), who assembled and interpolated measurements of the sea minus air difference in $\mathrm{CO}_{2}$ partial pressure $\left(\mathrm{pCO}_{2}\right)$ and estimated monthly mean net fluxes using a wind speed dependent gas exchange coefficient (Wanninkhof, 1992). Regions of maximum $\mathrm{CO}_{2}$ uptake by the ocean in July 1998 are located south of Spitzbergen and over the North Eastern Atlantic Ocean between Ireland and Southern Greenland (Fig. 3).

As fossil $\mathrm{CO}_{2}$ emissions, we used the Emission Database for Global Atmospheric Research (EDGAR V2.0) of Olivier et al. (1996), which consists of global $1^{\circ} \times 1^{\circ}$ maps of emissions from industry, heating, transportation and cement manufacturing. For this database national $\mathrm{CO}_{2}$ emissions are estimated using statistics on energy consumption (from IEA) and industrial production (from the United Nations) together with $\mathrm{CO}_{2}$-specific emission factors. The emissions are distributed within each country according to point-source and area-source information in combination with population density maps. Great Britain and Central Europe are the regions with highest emissions (Fig. 3). Only very few fossil sources are mapped north of $60{ }^{\circ} \mathrm{N}$, and there are almost no fossil sources in Northern Siberia. The EDGAR fossil $\mathrm{CO}_{2}$ emission map corresponds to the year 1990. Changes in geographic emission patterns between 1990 and 1998 with a decrease in Eastern Europe and Russia have been reported (Marland et al., 2000) see Trends Online http://cdiac.esd.ornl.gov/trends/trends. htm. Emissions were stable between 1990 and 1998 over western Europe, but they decreased by $20 \%$ in Russia and Eastern Europe. No seasonal nor diurnal pattern is attributed to fossil $\mathrm{CO}_{2}$ emissions, which are prescribed to the lowest model layer, assuming the maximum height at which industrial emissions are released to be $70 \mathrm{~m}$.

\subsection{Initial and boundary conditions}

For a long-lived trace gas like $\mathrm{CO}_{2}$, not only do local influences have to be accounted for in a regional simulation but also the role of sources and sinks outside the model domain is crucial. Therefore global $\mathrm{CO}_{2}$ mixing ratio fields are needed as initialisation and at the lateral boundaries during the model run. The importance of boundary conditions in REMO simulations was already shown for a short-lifetime gas, radon-222 (Chevillard et al., 2002) and for ozone (Langmann and Bauer, 2001). In the present study, initial and boundary conditions are provided by the global transport model TM3 (Heimann, 1995). The TM3 model has a horizontal resolution of $4^{\circ} \times 5^{\circ}$ along with 19 vertical layers, and provides concentrations fields at $3-\mathrm{hr}$ 
intervals. To ensure consistency when nesting REMO into TM3, the $\mathrm{CO}_{2}$ concentration is generated globally in TM3 with ECMWF transport fields that are identical to those used in REMO forcing. Similarly, the same set of $\mathrm{CO}_{2}$ surface fluxes are used in REMO and TM3. In TM3, the diurnal cycle of NEE is constructed from TURC in the same way as described for REMO forecast, except that meteorological information from ECMWF analyses are used. The TM3 model does not provide an absolute concentration of $\mathrm{CO}_{2}$. To compare model results to observations, we added an "offset" value, constant in time and space. This value (355 ppmv) has been determined such that the modelled $\mathrm{CO}_{2}$ concentration is closest to the observations at $3000 \mathrm{~m}$ at Fyodorovskoye and Zotino during July 1998.

\section{Results}

We discuss here the patterns of the atmospheric $\mathrm{CO}_{2}$ simulated by REMO in forecast mode. For each $\mathrm{CO}_{2}$ component (fossil, biospheric and oceanic), we firstly present the mean horizontal distribution over Europe and Western Siberia, secondly the temporal variability, and thirdly we discuss the specific influence of the boundary conditions. The last point is focused on the comparison between REMO climate and REMO forecast simulations.

\subsection{Modelled $\mathrm{CO}_{2}$ spatial distribution}

The REMO monthly averaged $\mathrm{CO}_{2}$ for July 1998 is presented in Fig. 5 for each component within the Atmospheric Boundary Layer (ABL). The $300 \mathrm{~m}$ level roughly represents the average height of the ABL. The $\mathrm{CO}_{2}$ distribution in this layer is not only dominated by the strong influence of the fluxes but also reflects the contribution of local and large-scale horizontal transport. It is immediately seen in Fig. 5b that the "classic" image of a north-south concentration gradient in latitude inferred from marine boundary layer measurements (Conway et al., 1994) leaves place to a more complex picture where east-west gradients between oceans and land are dominant. It is possible to evaluate separately the particular influence of each source to the overall $\mathrm{CO}_{2}$ concentration. Over central Europe, higher $\mathrm{CO}_{2}$ values are mainly caused locally by fossil fuel emissions (Figs. 5b and f). In Siberia, lower $\mathrm{CO}_{2}$ values reflect on the other hand the vegetation sink (Figs. 5b and d). Over the continents, the overall reduction of monthly $\mathrm{CO}_{2}$ in the $\mathrm{ABL}$ (Fig. 5b) due to uptake by photosynthesis exceeds in the monthly mean the increase due to respiratory release. The biospheric sink reduces $\mathrm{CO}_{2}$ in the boundary layer by approximately 2 ppmv in Central and Western Europe, and by 5 ppmv in Western Siberia as compared to the value over the ocean. We attribute this West to East negative gradient in biospheric $\mathrm{CO}_{2}$ within the ABL mainly to the increasing exposure of air to uptake by plants under the dominant westerly circulation. Note that "exposure" only occurs during daytime when the $300 \mathrm{~m}$ level is directly connected to the surface fluxes by vigorous mixing in the ABL. Interestingly, the simulated negative east minus west gradient at $300 \mathrm{~m}$ (Fig. 5d) is of opposite sign than the east minus west difference in NEE (Fig. 3), which shows less uptake in the east than the west.

In the western corner of the model domain (Fig. 5b), one can also detect the influence of uptake by vegetation over North America, which is advected across the North Atlantic towards Europe. This illustrates the importance of atmospheric transport acting on sources from outside the model area (Chevillard et al., 2002). The influence of the North Atlantic ocean sink on the $\mathrm{CO}_{2}$ concentration at $300 \mathrm{~m}$ over the continents is smaller than the one of the vegetation sink, but it is not negligible. Ocean uptake alone causes a reduction of $\mathrm{CO}_{2}$ concentration over north-western Europe and Scandinavia of $-0.5 \mathrm{ppmv}$ as compared to the interior of Siberia.

At $30 \mathrm{~m}$, the influence of the biospheric $\mathrm{CO}_{2}$ component results in average concentrations higher than just above (Figs. $4 \mathrm{c}$ and d). This effect results from the covariance between NEE and vertical mixing in the atmospheric boundary layer: at night, respired $\mathrm{CO}_{2}$ accumulates in the shallow nocturnal boundary layer, whereas, during the day, the signal of photosynthetic uptake is diluted over a deeper, often convective, air column (Denning et al., 1996). In contrast, a source with no diurnal variation, such as fossil fuel combustion or air sea exchange results in a contribution of the same sign on the $\mathrm{CO}_{2}$ distribution at every altitude: positive for the fossil emissions (Figs. 5e and f) and negative for the ocean uptake (Figs. $5 \mathrm{~g}$ and $\mathrm{h}$ ).

\subsection{Modelled $\mathrm{CO}_{2}$ temporal variability}

Figure 6 illustrates the temporal variability of $\mathrm{CO}_{2}$ in REMO, at three sites (Fig. 2): Schauinsland in western Europe, Fyodorovskoye in western Russia and Zotino in central Siberia. In the ABL, both at 30 and 

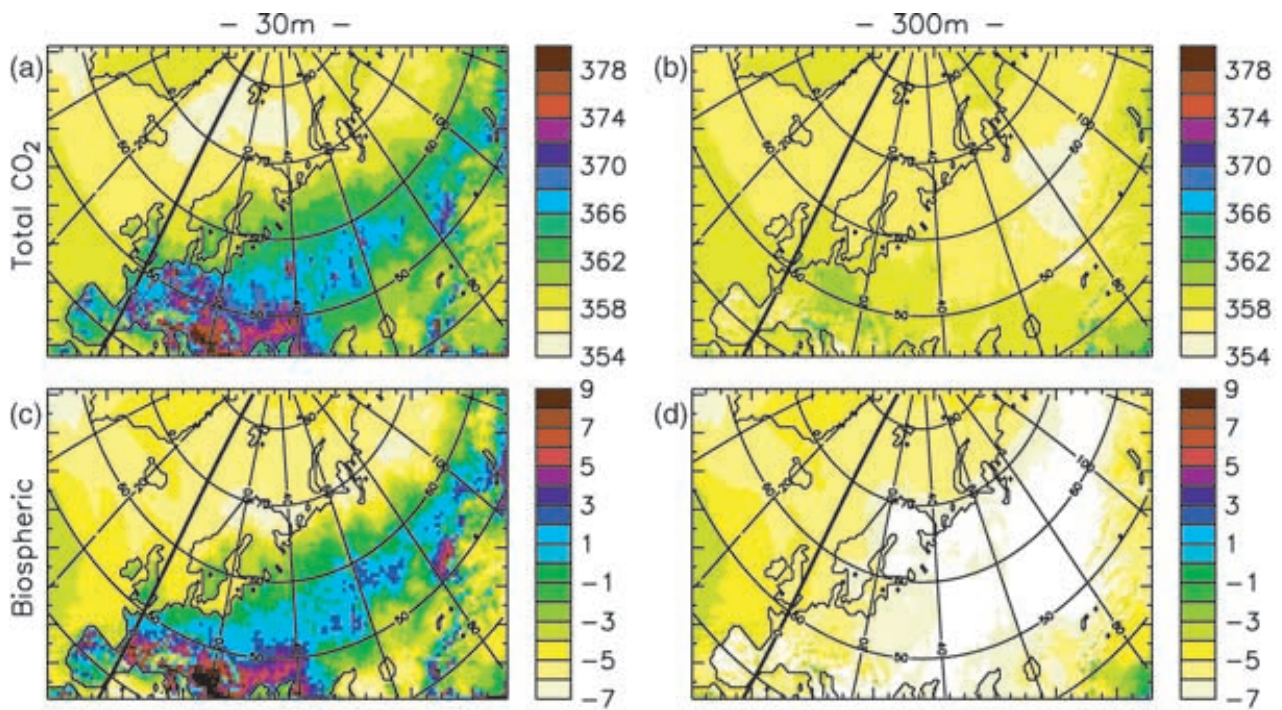

(d)
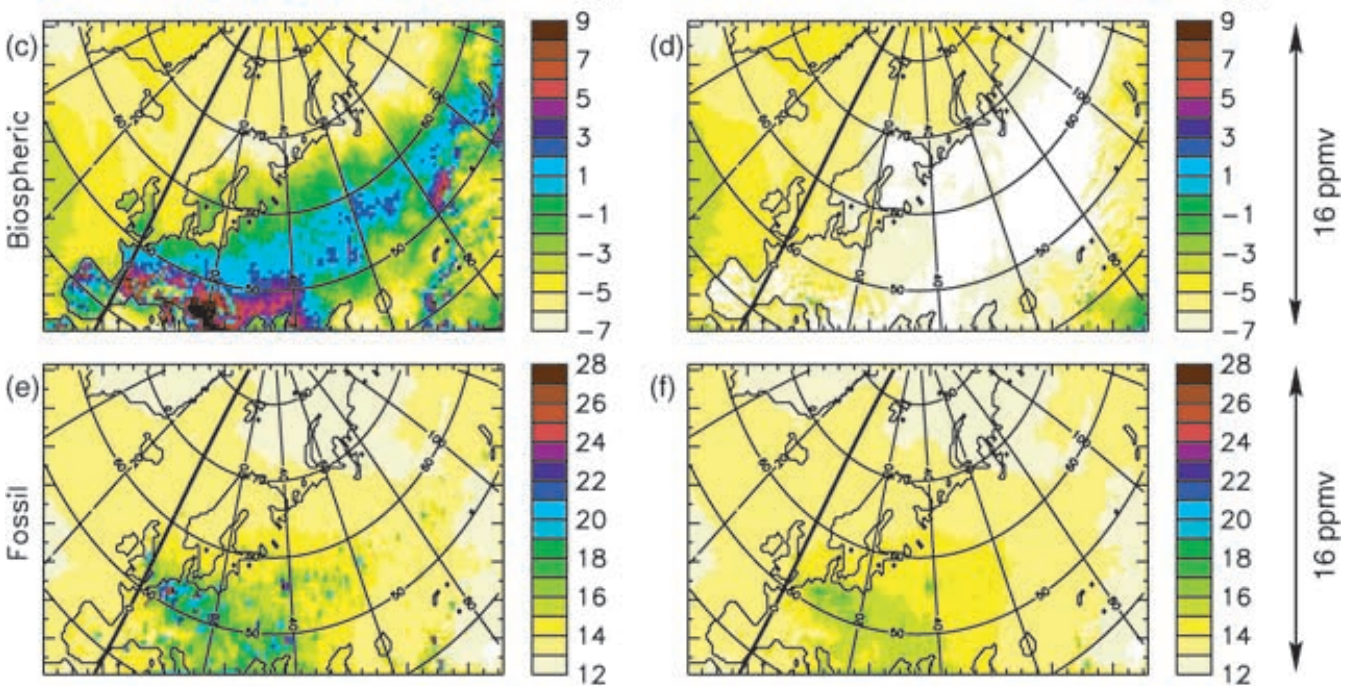

(f)
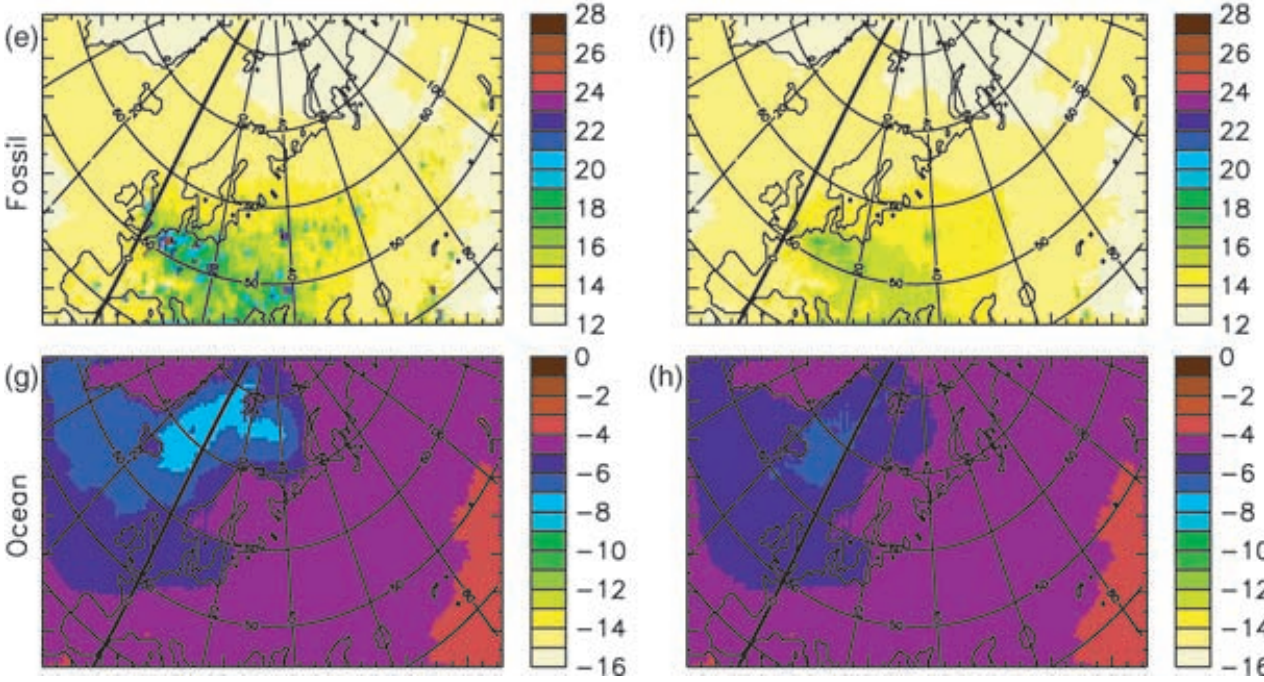

(h)
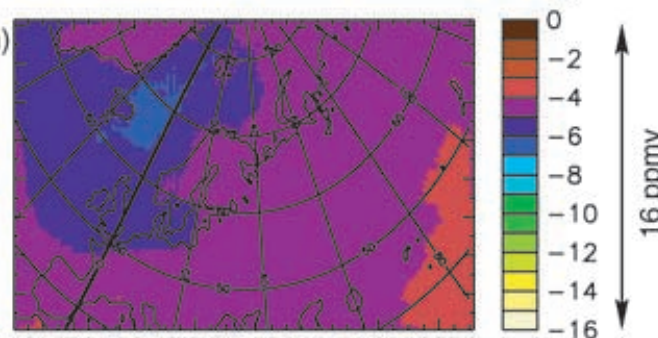

Fig. 5. Monthly means simulated $\mathrm{CO}_{2}$ mixing ratio (in ppmv) in July 1998 in the boundary layer at $30 \mathrm{~m}$ and $300 \mathrm{~m}$ above ground, the first two model vertical layers in REMO. (a) Total $\mathrm{CO}_{2}$ defined as the sum of fossil, biotic and ocean contributions of sources within the domain and of boundary conditions to which an arbitrary offset value of 355 ppmv is added. (b) Biospheric $\mathrm{CO}_{2}$ resulting from photosynthesis uptake and plant and soil respiration, including its boundary conditions. (c) Fossil $\mathrm{CO}_{2}$. (d) Ocean $\mathrm{CO}_{2}$.

$300 \mathrm{~m}$, the $\mathrm{CO}_{2}$ temporal variability is clearly driven by the terrestrial biosphere, and it is associated with a very strong diurnal cycle. In summer, the mean diurnal change in the biospheric $\mathrm{CO}_{2}$ component is induced by the covariance between NEE and vertical mixing in the atmospheric boundary layer (see above). At $300 \mathrm{~m}$, the daily amplitude of the biospheric $\mathrm{CO}_{2}$ component is much smaller than at $30 \mathrm{~m}$ and its phase is slightly shifted, approximately by $2 \mathrm{~h}$. Near the surface, the maximum of $\mathrm{CO}_{2}$ is observed in the early morning (at 5:00 AM) at Fyodorovskoye and Zotino. Generally, maximum release by respiration occurs about $2 \mathrm{~h}$ before the corresponding signal in $\mathrm{CO}_{2}$ concentration. The change in ABL depth occurs before the variations of the biospheric fluxes. In the lowermost free troposphere, on the other hand, the variability in 


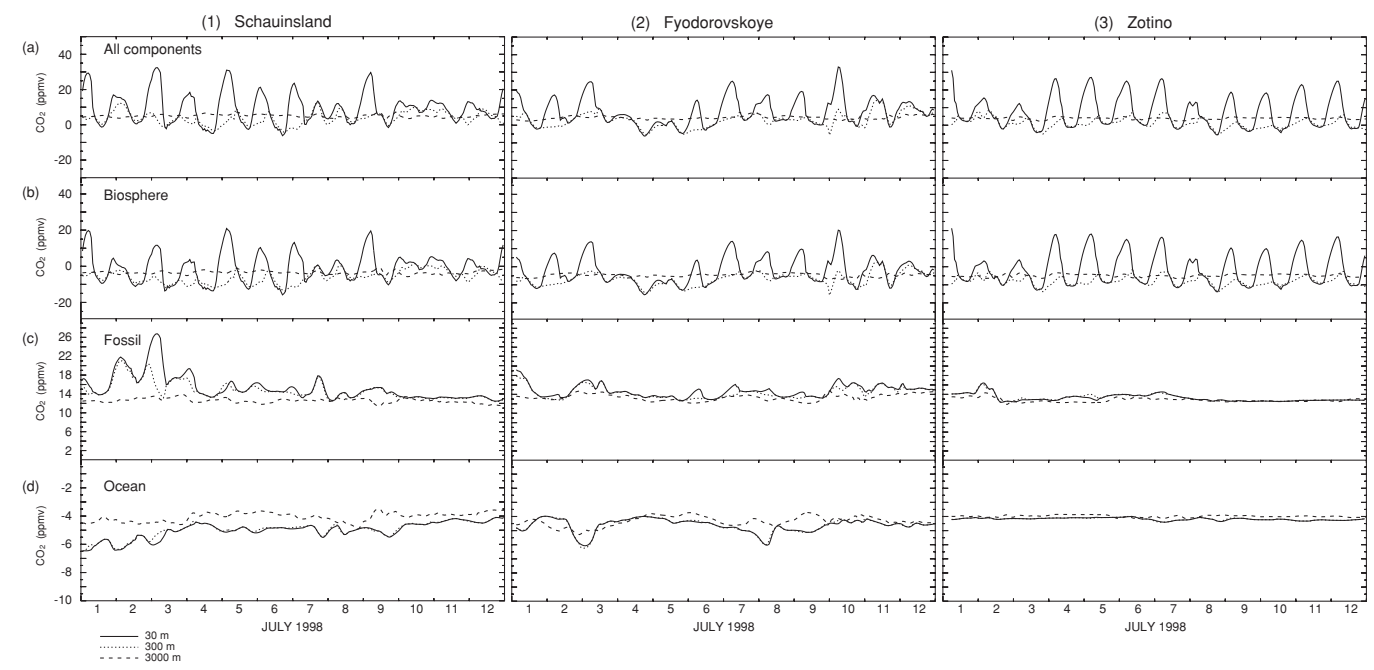

Fig. 6. Modelled and observed $\mathrm{CO}_{2}$ time series at Schauinsland (southern Germany), Fyodorovskoye (European Russia) and Zotino (central Siberia) during July 1998. (a) Total $\mathrm{CO}_{2}$, (b) biospheric, (c) oceanic, (d) fossil components are shown separates at $30 \mathrm{~m}$ (solid line), $300 \mathrm{~m}$ (dotted line) and $3000 \mathrm{~m}$ (dashed line).

$\mathrm{CO}_{2}$ concentration (Fig. 6) is much smaller than in the boundary layer, but is still dominantly influenced by the biospheric component.

The diurnal variability caused by the fossil $\mathrm{CO}_{2}$ component, albeit lower than the one due to biospheric $\mathrm{CO}_{2}$, is yet stronger at stations which are close to fossil fuel sources: Schauinsland and Fyodorovskoye (Fig. 6). Because in our simulation the fossil emissions are prescribed constant in time, the diurnal variation in the fossil $\mathrm{CO}_{2}$ component reflect only temporal changes in the transport. Note that, in order to produce a nocturnal increase in the fossil $\mathrm{CO}_{2}$ component at a given station, one needs fossil emissions in the vicinity of that station in the REMO model. In the "pristine" air of Siberia at Zotino, even though vertical transport varies between day and night, there is no daily cycle in fossil $\mathrm{CO}_{2}$ (Fig. 6c).

The diurnal variability of the ocean sink component gets strongly dampened over the interior of continents. At Schauinsland, in western Germany, there is no discernible diurnal variation of that component, whereas at Mace Head (not shown), the peak-to-peak amplitude of the ocean induced diurnal variation in $\mathrm{CO}_{2}$ is of 1 ppmv, a small signal as compared to the diurnal effect of the biosphere at this marine station.

It is also interesting to analyse the modelled variations in the daily cycle of atmospheric $\mathrm{CO}_{2}$ from one day to the next. At Zotino for instance, during July 1998, the REMO model produces a fairly regular di- urnal cycle with an amplitude of 20-25 ppmv near the surface and of 4-7 ppmv at $300 \mathrm{~m}$. The Zotino area is under the influence of stationary high-pressure systems most of the time. In high-pressure regions the ABL usually shows a very well defined structure with a turbulent mixed layer during the day and a shallow stable nocturnal boundary layer with a residual layer aloft containing former mixed layer air (Stull, 1988). Only on some occasions (e.g. July 8) do passing lowpressure systems cause a reduction of the diurnal amplitude of biospheric $\mathrm{CO}_{2}$ due to stronger and higher reaching turbulent mixing, especially during the night. At Fyodorovskoye and Schauinsland, the diurnal cycle amplitude of the biospheric component is more irregular than at Zotino. Both stations are more frequently influenced by the alternance of passing frontal systems and periods of high pressure. A comparison of the simulated surface pressure with the observed pressure (not shown) shows that the model is reproducing this sequence with a correct timing. During periods of high pressure the daily amplitude of the biospheric $\mathrm{CO}_{2}$ component is larger compared to Zotino, reaching up to $40 \mathrm{ppmv}$ at Fyodorovskoye and $50 \mathrm{ppmv}$ at Schauinsland. In these situations the local conditions and the vertical exchange are mainly determining the $\mathrm{CO}_{2}$ distribution. During the passage of frontal systems, synoptic scale turbulence dominates the fluctuations of the $\mathrm{CO}_{2}$ concentration. At $300 \mathrm{~m}$, the diurnal variations are less regular than the ones closer to the 


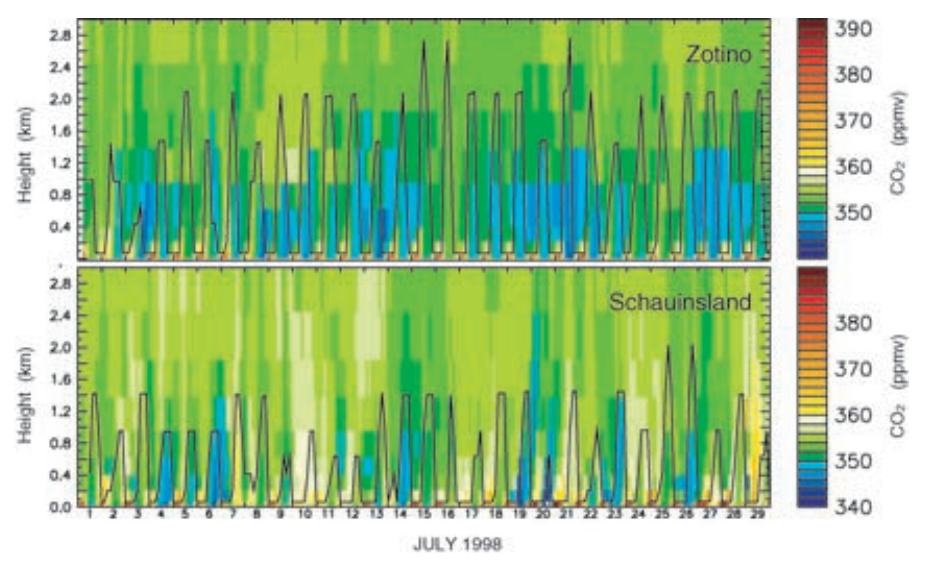

Fig. 7. Modelled time series of the vertical variability of $\mathrm{CO}_{2}$ within the atmospheric boundary layer and the lower troposphere at Zotino and Schauinsland. The simulated boundary layer height is indicated by a black line. Note the nocturnal accumulation of respired $\mathrm{CO}_{2}$ near the surface and the daytime dilution of plant uptake by convection.

surface. This indicates that the $\mathrm{CO}_{2}$ concentration is, at this height, more strongly influenced by the largescale synoptic transport.

Time series of the vertical $\mathrm{CO}_{2}$ distribution in the lowest $3000 \mathrm{~m}$ of the troposphere are shown for Zotino and Schauinsland in Fig. 7, together with estimates of the ABL height. The correlation between the sign of biospheric fluxes and ABL turbulence results in a time-mean vertical $\mathrm{CO}_{2}$ structure with: (1) a layer of comparatively low $\mathrm{CO}_{2}$ concentrations in the planetary boundary layer due to photosynthesis and (2) higher values near the surface due to respiration. $\mathrm{CO}_{2}$ depleted air is mixed up in the daytime ABL compared to $\mathrm{CO}_{2}$ enriched air during stable conditions at night. Above the $\mathrm{ABL}$ the $\mathrm{CO}_{2}$ distribution is mainly influenced by the large scale transport and much less variable. At Zotino, where high-pressure situations with a regular diurnal cycle of turbulence in the $\mathrm{ABL}$ are prevailing, the separation between $\mathrm{CO}_{2}$ enriched air near the surface and $\mathrm{CO}_{2}$ depleted air above is clearly visible (Figure 7). At Schauinsland, the stronger vertical exchange caused by the larger-scale turbulence connected to the passing low-pressure systems is reflected in the $\mathrm{CO}_{2}$ concentration pattern.

\subsection{Influence of boundary and initial conditions}

The simulated $\mathrm{CO}_{2}$ concentration in each grid cell results from the superposition of (1) $\mathrm{CO}_{2}$ emitted from sources inside the model domain, (2) $\mathrm{CO}_{2}$ transported across the lateral boundaries, and (3) $\mathrm{CO}_{2}$ introduced at the initialisation. Initial and boundary concentra- tions both represent the contribution of the global emissions in the TM3 simulation, after steady state has been approached (4 yr). Initial and boundary conditions for the simulation of $\mathrm{CO}_{2}$ were transported in this study as three separate components. For instance, one can see, in Fig. 8, that the fossil fuel component almost entirely reflects the influence of emissions from outside the model domain and prior to the start of the simulation. Initial conditions clearly dominate the signal during the first $6 \mathrm{~d}$ and afterwards are gradually replaced by information from the boundaries conditions (Figs. 8a and b). Conversely, at stations closer to the boundaries the influence of initial conditions is of shorter duration, e.g. $3 \mathrm{~d}$ only at Mace Head.

On the other hand, the biospheric component at Zotino is largely influenced by internal sources. In the lowest level, the contribution of initial and boundary conditions is small (Fig. 8c). Above the ABL, the influence of internal sources decreases and initial and boundary conditions become more important, while the temporal variability is of similar amplitude in all components (Fig. 8d). In general, the average $\mathrm{CO}_{2}$ above the ABL is determined by short-term initial and boundary conditions, whereas temporal variations are equally influenced by internal and external sources. Within the ABL, local sources have a dominant influence.

\subsection{Comparison between REMO "forecast" and REMO "climate"}

In this part, we study the difference between the two modes of REMO (climate and forecast) on the 


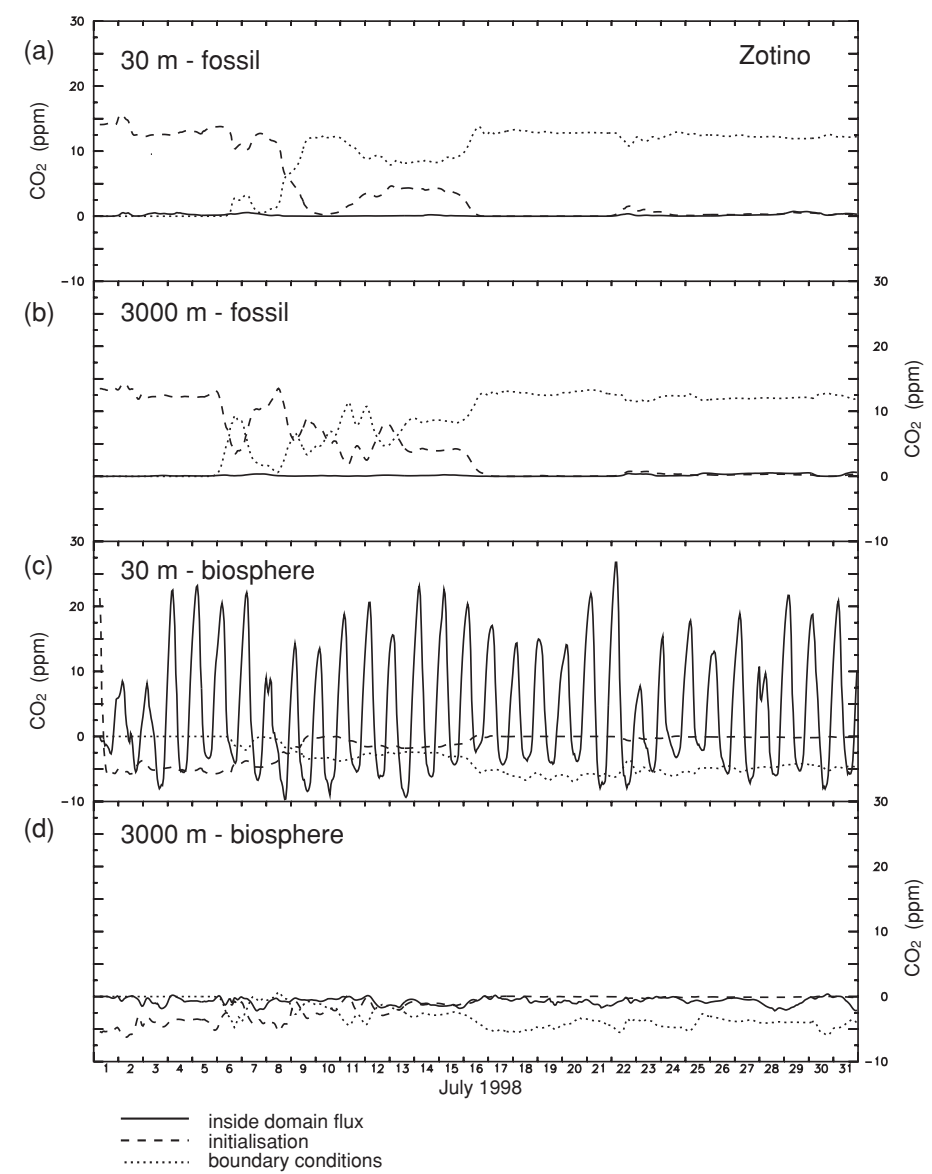

Fig. 8. Illustration of the role of initial and boundary conditions with respect to transport of sources within the domain at Zotino (central Siberia). (a) Fossil $\mathrm{CO}_{2}$ time series at $30 \mathrm{~m}$. (b) Fossil $\mathrm{CO}_{2}$ time series at $3000 \mathrm{~m}$. (c) Biospheric $\mathrm{CO}_{2}$ at $30 \mathrm{~m}$. (d) Biospheric $\mathrm{CO}_{2}$ at $3000 \mathrm{~m}$.

simulated $\mathrm{CO}_{2}$ concentrations. The version of REMO run in climate mode is initialised on 1 March 1998 and computes its own climate, contrarily to REMO run in forecast mode which is readjusted everywhere each day to the ECMWF analysis. The climate and ancillary atmospheric tracer transport are consequently different between the two versions of the same model.

Overall, differences in monthly mean $\mathrm{CO}_{2}$ concentration simulated by both model versions are large in the centre of the domain. Close to the lateral boundaries, the concentrations are very similar, consequences of (1) the same 6 hourly forcing by ECMWF fields and (2) the same 3 hourly prescribed $\mathrm{CO}_{2}$ concentration fields from the global model TM3. On average over the whole domain, the $\mathrm{CO}_{2}$ concentration difference between climate and forecast modes is $1.0 \pm$ $1.1 \mathrm{ppmv}$ close to the surface and $0.6 \pm 0.4 \mathrm{ppmv}$ at $500 \mathrm{~m}$ above ground.

First, a comparison of monthly fossil and oceanic $\mathrm{CO}_{2}$ components is performed (not shown), since those components have identical surface sources in both REMO modes. In the REMO-climate simulation, the oceanic $\mathrm{CO}_{2}$ is spread out from the North Atlantic towards Scandinavia and northern Russia, in the lowest model layer, whereas it stays centred over the North Atlantic in the REMO forecast mode. This reflects a stronger westerly transport in REMO climate. Similarly, the fossil $\mathrm{CO}_{2}$ component at $3000 \mathrm{~m}$ in REMO climate is more widespread towards the east (western Siberia), than in the REMO forecast run. At $300 \mathrm{~m}$ 


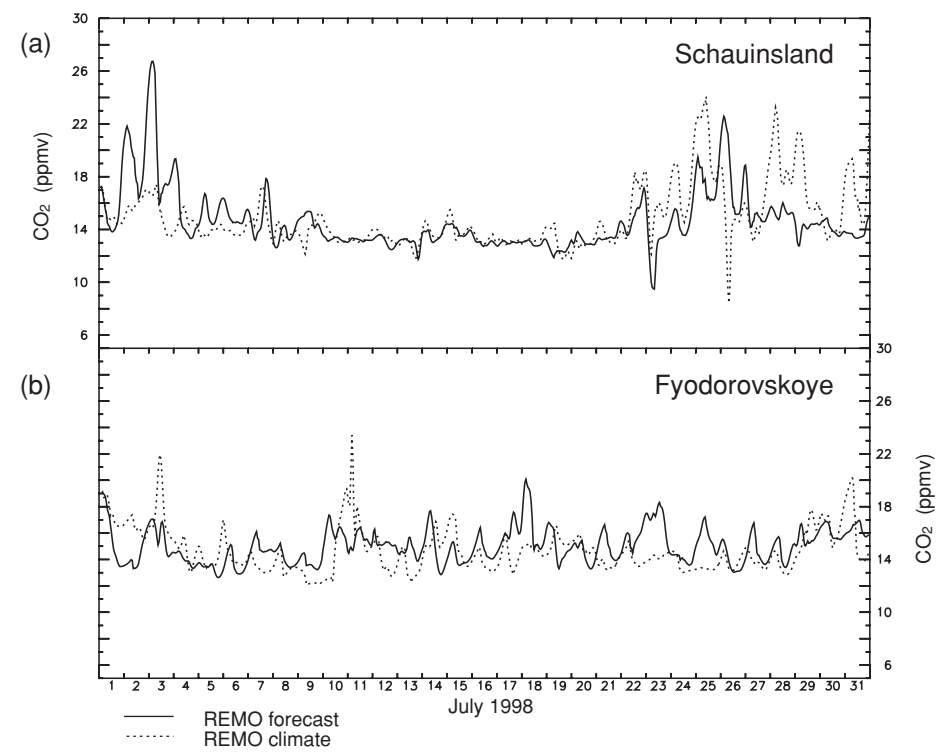

Fig. 9. Illustration of the differences between two versions "forecast" and "climate" of REMO. Time series of fossil $\mathrm{CO}_{2}$ simulated by both versions of the model are given (a) at Schauinsland and (b) at Fyodorovskoye.

over Europe, where long range transport processes have a smaller influence on the fossil concentration than short range transport acting on nearby sources, both REMO climate and REMO forecast simulations give fairly similar results.

Figure 9 shows the time series of fossil $\mathrm{CO}_{2}$ concentrations simulated by both versions of REMO at Schauinsland and Fyodorovskoye. At Schauinsland, a mountain station near an industrial emission area, fossil $\mathrm{CO}_{2}$ transported by REMO forecast is very close to the one simulated in REMO climate over the period of 9-20 July 1998, whereas both model versions differ elsewhere. The period when both model versions agree corresponds to the passage of a frontal system with high winds, during which the influence of boundary conditions (similar in both model versions) is dominantly felt at Schauinsland. On the other hand, intervals when the model versions disagree correspond to the establishment of more local conditions. At Fyodorovskoye, that is located further away from industrialised emissions, the diurnal cycle of fossil $\mathrm{CO}_{2}$ has a smaller amplitude than at Schauinsland in both versions of REMO (Fig. 9a). The variability of fossil $\mathrm{CO}_{2}$ time series in the two versions is however very different, because far from the lateral boundaries, REMO in climate mode generates a distinct meteorology.
In the following comparison with measurements, results of REMO in the forecast mode are presented, since its simulated meteorology is closer to the observations. Lafont et al. (2002) showed in their study that the meteorological input fields used in TURC have a strong influence on the spatial and temporal patterns of the simulated NEE. Nevertheless, the comparison shows that, even in the climate mode, the model gives a realistic representation of the temporal and spatial characteristics of atmospheric processes (section 2) and tracer transport.

\section{Comparison with atmospheric $\mathrm{CO}_{2}$ measurements}

\subsection{Modelled and observed $\mathrm{CO}_{2}$ variability at different stations}

Time series of simulated $\mathrm{CO}_{2}$ concentrations are compared with measurements (Fig. 10) during July 1998 at five different sites: Mace Head (coastal station), Schauinsland (mountain station), Hegyhátsál (tall tower) and Fyodorovskoye and Zotino (two short towers at each site with concentration records above forest and bog canopies). A caution flag should be raised regarding comparison between model 


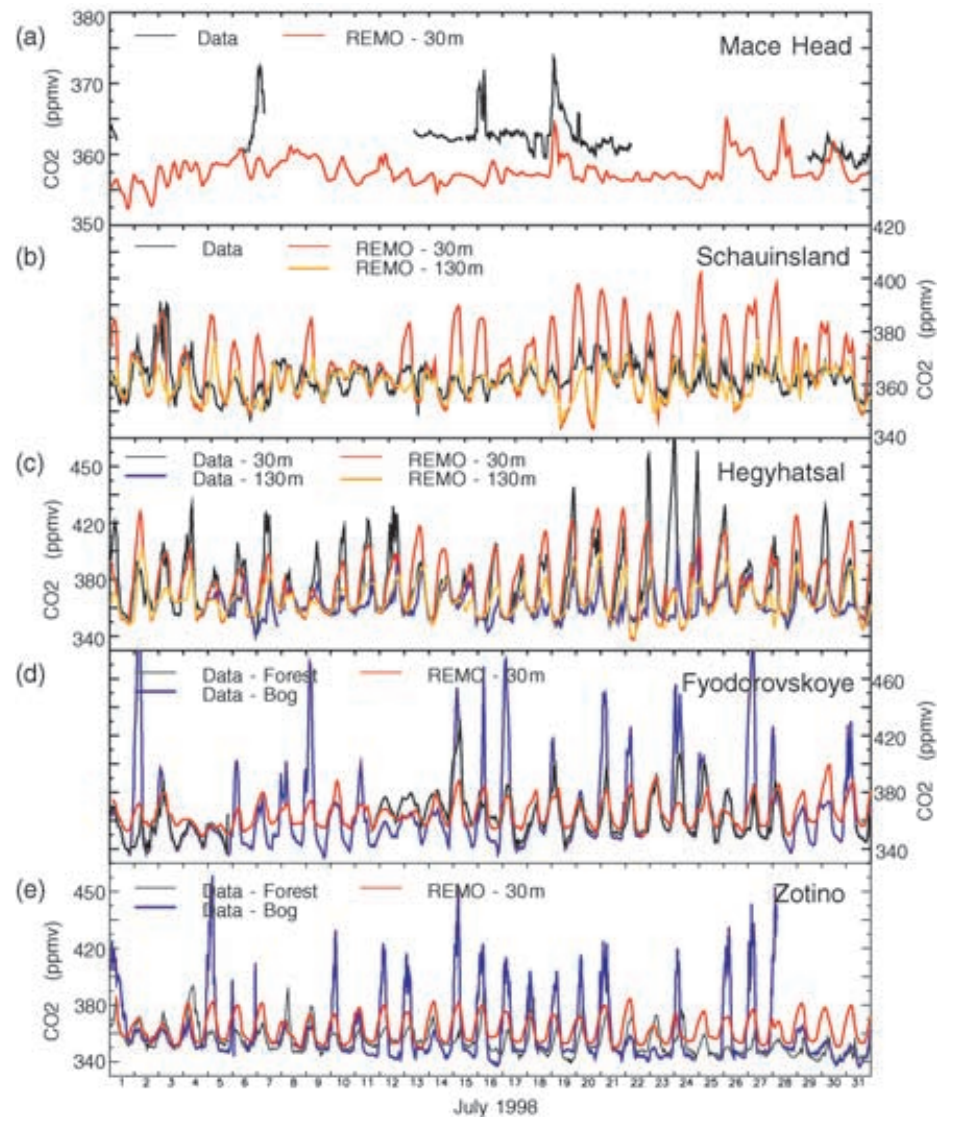

Fig. 10. Observed and simulated (red) atmospheric $\mathrm{CO}_{2}$ mixing ratios from the North Atlantic Ocean to central Siberia at Mace Head, Schauinsland, Hegyhátsál, Fyodorovskoye and Zotino. At Fyodorovskoye and at Zotino, the observations are shown both over a bog at $8 \mathrm{~m}$ (blue) and forest canopy at $30 \mathrm{~m}$ (black) that are located within the same model grid cell. At Hegyhátsál, a tall tower, $\mathrm{CO}_{2}$ measured at two different heights is compared with the first two lower model layers. Red line, REMO simulation at $30 \mathrm{~m}$ above model ground; orange line, REMO at $130 \mathrm{~m}$ a.m.g.

observations at only a few stations: this approach is necessary but not sufficient for a comprehensive model verification. Besides, although stations are generally chosen to be representative of large regions, $\mathrm{CO}_{2}$ may be influenced by local conditions, not accounted for in a model of average grid size of $55 \mathrm{~km}$.

The observed $\mathrm{CO}_{2}$ concentration at Mace Head exhibits a stable marine baseline over which are superimposed $\mathrm{CO}_{2}$ peaks of 10 ppmv (6,15 and 18 July). Those peaks lasting from a few hours up to a few days are related to sudden changes in the wind direction from well established west direction (ocean) to south or east (land) and to a decrease in wind speed. A rapid increase of the wind speed, associated with a return to westerly winds, brings back the $\mathrm{CO}_{2}$ concentration to the baseline value. The simulated standard deviation of $\mathrm{CO}_{2}$ is about half the observed value (Table 3 ). Only the peak of 18 July is reproduced by REMO (Figure 10a), which explains the poor model data correlation in Table 4. 18 July is the longest and best defined synoptic "event" in July, for which the wind speed and direction changes are exactly reproduced by the model. The $\mathrm{CO}_{2}$ emitted inside the REMO domain by the biospheric source is the only component that contributes to this peak. The amplitude of the peak is, however, underestimated (by $5 \mathrm{ppmv}$ ). On the other hand, two shorter duration peaks in 6 and 15 July are not represented in REMO because they correspond to very local conditions (wind speeds $<5 \mathrm{~m} \mathrm{~s}^{-1}$ ) that are not resolved at the model's resolution, a mismatch also 
Table 3. Monthly means and standard deviation of $\mathrm{CO}_{2}$ mixing ratio (ppmv)

\begin{tabular}{lllll}
\hline Atmospheric $\mathrm{CO}_{2}$ & REMO forecast & REMO climate & TM3 & Observations \\
\hline MHD & $357.4 \pm 1.5$ & $360.7 \pm 0.8$ & $357.0 \pm 1.6$ & $362.4 \pm 2.8$ \\
$\mathbf{S C H - 3 0 ~ m}$ & $366.9 \pm 11.1$ & $366.9 \pm 9.7$ & $368.4 \pm 12.1$ & $362.3 \pm 5.7$ \\
$\mathbf{S C H}-130$ m & $360.9 \pm 5.3$ & $362.4 \pm 5.7$ & $363.3 \pm 4.5$ & \\
HUN-30 m & $376.3 \pm 20.1$ & $377.2 \pm 18.6$ & $371.6 \pm 5.9$ & $372.5 \pm 18.6$ \\
HUN-130 m & $365.6 \pm 11.0$ & $367.9 \pm 10.4$ & $363.6 \pm 5.4$ & $361.8 \pm 8.8$ \\
TVR-forest & $364.4 \pm 9.4$ & $367.1 \pm 9.1$ & $367.2 \pm 10.3$ & $362.8 \pm 15.5$ \\
ZOT-forest & $362.8 \pm 8.9$ & $367.6 \pm 9.0$ & $361.9 \pm 8.5$ & $353.0 \pm 8.9$ \\
\hline
\end{tabular}

Table 4. Monthly mean peak-to-peak amplitude of $\mathrm{CO}_{2}$ mixing ratio $(p p m v)^{\mathrm{a}}$

\begin{tabular}{|c|c|c|c|c|}
\hline Atmospheric $\mathrm{CO}_{2}$ & REMO forecast & REMO climate & TM3 & Observations \\
\hline MHD & $\begin{array}{c}3.2 \pm 1.9 \\
(0.35)\end{array}$ & $\begin{array}{c}2.5 \pm 1.5 \\
(0.20)\end{array}$ & $\begin{array}{c}2.2 \pm 1.0 \\
(0.09)\end{array}$ & $4.3 \pm 3.4$ \\
\hline $\mathrm{SCH}-30 \mathrm{~m}$ & $\begin{array}{c}30.5 \pm 10.5 \\
\quad(0.42)\end{array}$ & $\begin{array}{c}26.3 \pm 12.7 \\
(0.38)\end{array}$ & $\begin{array}{c}27.5 \pm 17.4 \\
(0.32)\end{array}$ & $12.6 \pm 6.5$ \\
\hline $\mathrm{SCH}-130 \mathrm{~m}$ & $\begin{array}{c}13.8 \pm 5.2 \\
\quad(0.30)\end{array}$ & $\begin{array}{c}12.4 \pm 6.1 \\
(0.22)\end{array}$ & $\begin{array}{c}11.5 \pm 3.5 \\
(0.25)\end{array}$ & \\
\hline HUN - $30 \mathrm{~m}$ & $\begin{array}{c}51.6 \pm 17.6 \\
(0.30)\end{array}$ & $\begin{array}{c}46.3 \pm 14.8 \\
(0.50)\end{array}$ & $\begin{array}{c}35.8 \pm 19.4 \\
(0.67)\end{array}$ & $52.8 \pm 20.9$ \\
\hline HUN - 130 m & $\begin{array}{c}27.7 \pm 11.6 \\
(0.51)\end{array}$ & $\begin{array}{c}25.0 \pm 11.7 \\
\quad(0.46)\end{array}$ & $\begin{array}{c}13.0 \pm 5.8 \\
\quad(0.41)\end{array}$ & $27.2 \pm 10.4$ \\
\hline $\begin{array}{l}\text { TVR } \\
\text { Forest } \\
\text { Bog }\end{array}$ & $\begin{array}{c}24.2 \pm 7.9 \\
(0.73) \\
(0.61)\end{array}$ & $\begin{array}{c}25.1 \pm 6.2 \\
\quad(0.62) \\
(0.59)\end{array}$ & $\begin{array}{c}23.6 \pm 9.4 \\
(0.74) \\
(0.70)\end{array}$ & $\begin{array}{l}39.5 \pm 16.0 \\
84.9 \pm 40.1\end{array}$ \\
\hline $\begin{array}{l}\text { ZOT } \\
\text { Forest } \\
\text { Bog }\end{array}$ & $\begin{array}{c}25.2 \pm 4.6 \\
(0.51) \\
(0.64)\end{array}$ & $\begin{array}{c}24.8 \pm 6.4 \\
(0.41) \\
(0.55)\end{array}$ & $\begin{array}{c}22.3 \pm 8.2 \\
(0.61) \\
(0.77)\end{array}$ & $\begin{array}{l}24.1 \pm 10.2 \\
59.2 \pm 34.4\end{array}$ \\
\hline
\end{tabular}

${ }^{\mathrm{a}}$ The correlation coefficient between model and observations is indicated in parenthesis.

confirmed by ${ }^{222} \mathrm{Rn}$ simulations in Chevillard et al. (2002). At Mace Head, the simulation of $\mathrm{CO}_{2}$ depends much on the quality of the wind fields. For this study, we found that it is preferable to screen out local "events" (Biraud et al., 2002) from the observed record when trying to invert $\mathrm{CO}_{2}$ fluxes using an atmospheric transport model.

At Schauinsland, the observed $\mathrm{CO}_{2}$ diurnal cycle is small as compared to short towers just above the canopy. In the afternoon, the mountain station is in the well mixed ABL: photosynthesis exceeds respiration and the air is depleted in $\mathrm{CO}_{2}$. During the night, formation of a shallow nocturnal boundary layer prevents the air enriched in $\mathrm{CO}_{2}$ by respiration from reaching the mountain station. Therefore, biotic exchange controls the $\mathrm{CO}_{2}$ daily cycle, but, when the station is influenced by local conditions (e.g. 1-4 July), regional fossil $\mathrm{CO}_{2}$ can also significantly contribute to it (Fig. 6c). The altitude of the station is $1205 \mathrm{~m}$ a.s.l., whereas the model ground is $700 \mathrm{~m}$ a.s.l. high, and one can therefore wonder what is the most adequate vertical location of the station in the model. Comparison between observed and modelled $\mathrm{CO}_{2}$ suggests that the layer at $130 \mathrm{~m}$ above ground ( $830 \mathrm{~m}$ a.s.l.) would best match both the daily amplitude and monthly mean value of $\mathrm{CO}_{2}$ (Table 3). Yet, the phase of the daily $\mathrm{CO}_{2}$ oscillation is more realistic cycle at $30 \mathrm{~m}$ (Table 4), as is the simulated ${ }^{222} \mathrm{Rn}$ amplitude (Chevillard et al., 2002). Differences between both model layers (up to $30 \mathrm{ppmv}$ ) occur only during the night (Fig. 10b), when respiration increases $\mathrm{CO}_{2}$ near the ground. The afternoon $\mathrm{CO}_{2}$ values at both 30 and $130 \mathrm{~m}$ are similar, due to 
strong turbulence in the ABL. We thus recommend the use of only selected mid-afternoon data in REMO, because they can be more robustly reproduced by either of the first two model layers. Night-time accumulation effects at a mountain station are almost impossible to simulate realistically when the model resolution is smoother than the observed topography.

At the tall tower in Hegyhátsál, $\mathrm{CO}_{2}$ is measured at respectively 10, 48, 82 and $115 \mathrm{~m}$ (Appendix). We compared REMO at $30 \mathrm{~m}$ (respectively at $130 \mathrm{~m}$ ) with observations interpolated (respectively extrapolated) between the bracketing measurement heights assuming a logarithmic profile of $\mathrm{CO}_{2}$. The data show a large diurnal oscillation with a higher night-time maximum by $25 \mathrm{ppmv}$ at $30 \mathrm{~m}$ compared to $130 \mathrm{~m}$, as implied by strong gradients of respired $\mathrm{CO}_{2}$ near the ground under stable nocturnal conditions. Both levels, however, show similar $\mathrm{CO}_{2}$ mixing ratios which differ by less than 1.2 ppmv during mid-afternoon when the $\mathrm{ABL}$ is well mixed At $130 \mathrm{~m}$, REMO reproduces well the observed variability (Table 3 ), and the phase and amplitude of the diurnal cycle (data not shown). At $30 \mathrm{~m}$, the modelled phase signal is realistic, but the simulated nighttime maximum (at 06:00) is underestimated by 15 ppmv. Given the fact that the simulated nocturnal respiration is correctly matching the local eddy covariance data (Fig. 4), we can conclude that the night-time vertical mixing in REMO is too strong. Similar conclusions were independently obtained based on ${ }^{222} \mathrm{Rn}$ in Chevillard et al. (2002). In summary, we found that the simulated daytime $\mathrm{CO}_{2}$ on a tall tower can be robustly compared to observations at each height of the profile. In contrast, the simulated night-time $\mathrm{CO}_{2}$ can only be safely compared with data if the tower reaches up high enough. This suggests that tall towers are much more valuable than short towers in providing systematic data for $\mathrm{CO}_{2}$ sources and sink inferences in atmospheric transport models.

At Fyodorovskoye, $\mathrm{CO}_{2}$ shows a large diurnal oscillation over the spruce forest canopy (40 ppmv). Note, however, that $\mathrm{CO}_{2}$ is measured at this site to evaluate the night-time storage terms affecting NEE (Milyukova et al., 2002), and thereby it is not precisely calibrated against air standards as done at atmospheric stations. The accuracy of $\mathrm{CO}_{2}$ measurements on top of flux towers at Fyodorovskoye and Zotino is estimated to be on the order of $10 \mathrm{ppmv}$ (Milyukova et al., 2002). Nevertheless, such data are useful to compare with REMO for the phase and typical amplitude of the daily signal. The observed nocturnal $\mathrm{CO}_{2}$ built-up over the bog is huge (ampli- tude $85 \mathrm{ppmv}$ ), but the bog tower is too close to the ground $(8 \mathrm{~m})$ to allow proper comparison with REMO. This is confirmed by a higher correlation between modelled $\mathrm{CO}_{2}$ and observed $\mathrm{CO}_{2}$ at the forest tower $(30 \mathrm{~m})$ than at the bog tower (Table 4). Figure $10 \mathrm{~d}$ shows that REMO underestimates the daily amplitude of $\mathrm{CO}_{2}$ over the forest canopy (Table 3), which is not surprising because the amplitude of the modelled NEE is also underestimated. In fact, the spruce forest stand is a source to the atmosphere on a daily average even during July because of the site history (Milyukova et al., 2002), a feature that can not be captured within the simplified annually balanced TURC diagnostic model.

At Zotino, the daily oscillation of $\mathrm{CO}_{2}$ above the pine forest canopy shows a lower peak-to-peak amplitude (24.1 ppmv) than at Fyodorovskoye. This reflects a smaller peak-to-peak amplitude of NEE $(130.8 \mu \mathrm{gC}$ $\mathrm{m}^{-2} \mathrm{~s}^{-1}$ against $360 \mu \mathrm{gC} \mathrm{m} \mathrm{m}^{-2} \mathrm{~s}^{-1}$ at Fyodorovskoye) as well as differences in vertical mixing between Central Siberia and European Russia. Inspection of the ratio between the amplitude of NEE and the amplitude of $\mathrm{CO}_{2}$ above the canopy at both sites suggests that the nocturnal stability of the boundary layer is more pronounced (or more frequent) in central Siberia than in European Russia, where more frontal systems reach the site and break down the nocturnal stratification. As for Fyodorovskoye, we discarded comparison between REMO and the bog $\mathrm{CO}_{2}$ measurements at $8 \mathrm{~m}$ above ground. Figure $10 \mathrm{e}$ shows that REMO correctly reproduces the amplitude of the daily cycle in $\mathrm{CO}_{2}$ (Table 4), and even some of the synoptic variations, such as the persistent decrease in daytime $\mathrm{CO}_{2}$ minima between 15 July and 20 July.

\subsection{Modelled and observed $\mathrm{CO}_{2}$ diurnal variability in vertical profiles}

In order to investigate the performances of REMO in simulating the vertical variability of $\mathrm{CO}_{2}$, the model results are compared with measured $\mathrm{CO}_{2}$ vertical profiles. During the EUROSIBERIAN CARBONFLUX project, aircraft measurements of $\mathrm{CO}_{2}$ concentration profiles were performed at Fyodorovskoye and Zotino in July 1998 three times a day during intensive campaigns (Ramonet et al., 2002; Lloyd et al., 2002; Styles et al., 2002). We use here continuous vertical $\mathrm{CO}_{2}$ profiles sampled from $10 \mathrm{~m}$ up to $3000 \mathrm{~m}$ during several consecutive days in July 1998.

A comparison of REMO with vertical profiles is given in Fig. 11. The time-varying vertical structure of 

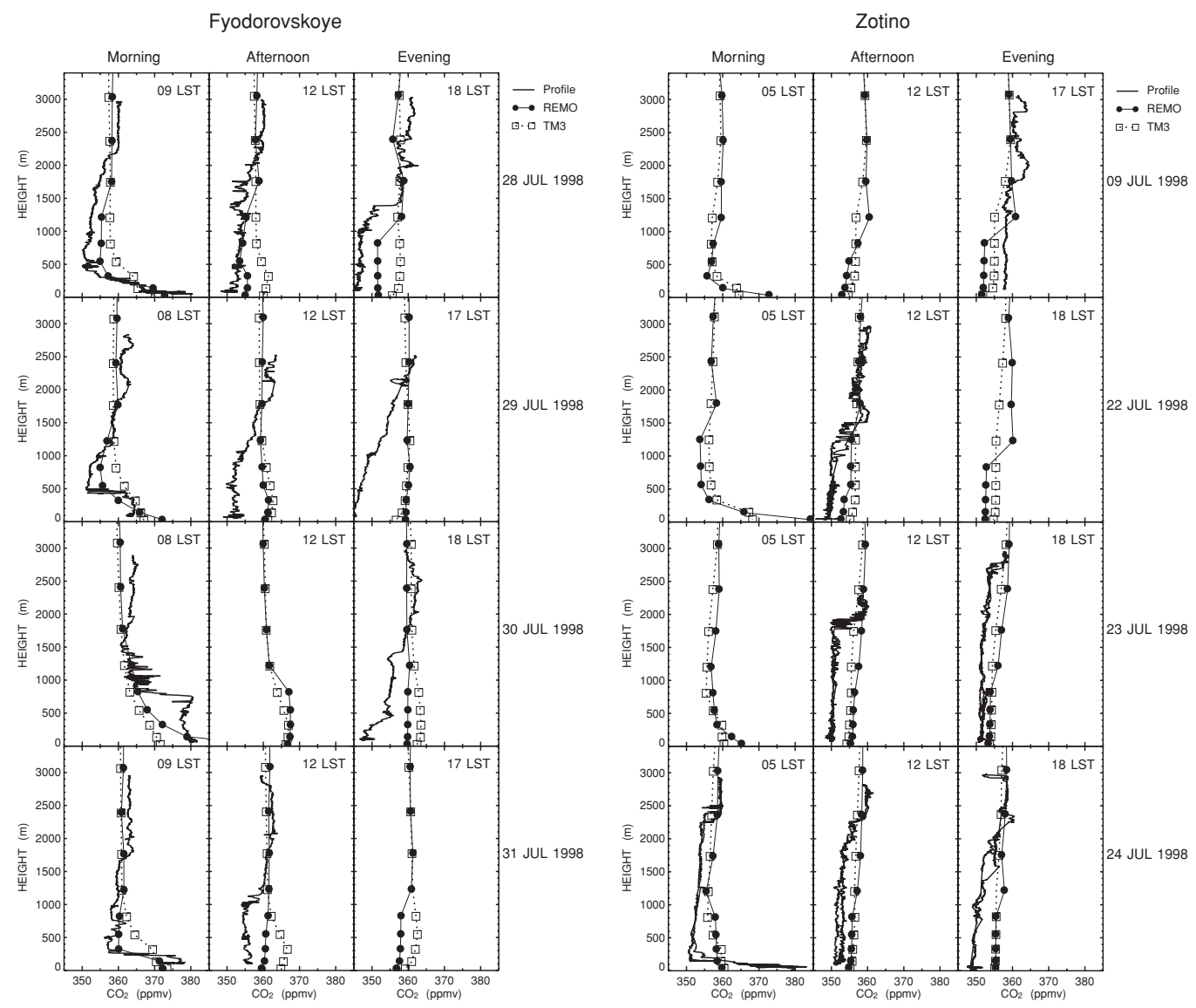

Fig. 11. Observed and modelled vertical profiles of $\mathrm{CO}_{2}$ during an intensive period of observation in July 1998 where aircraft in-situ $\mathrm{CO}_{2}$ vertical profiles were sampled in the morning, early afternoon and evening. Simulations by the fine resolution model REMO and by the coarse resolution model TM3 are represented. Left, Fyodorovskoye intensive campaign (2831 July); right, Zotino intensive campaign (9-24 July).

simulated $\mathrm{CO}_{2}$ at Zotino in July 1998 is also presented in Fig. 7. In Figure 11 the profiles are arranged in such a way that morning, early afternoon and evening flights at each site are grouped together. REMO has nine layers of increasing thickness between the surface and $3000 \mathrm{~m}$.

For the two intensive aircraft campaigns, the measurements show similar variability with small $\mathrm{CO}_{2}$ variations at $3000 \mathrm{~m}$ and large diurnal changes within the ABL. The $\mathrm{CO}_{2}$ concentration in the upper part of the profiles (near $3000 \mathrm{~m}$ ) that is representative for the free troposphere is used to determine a constant offset value. In general, the morning profiles show an accumulation of respired $\mathrm{CO}_{2}$ near the surface below $500 \mathrm{~m}$ and a sharp decrease of the concentration above. At noon, the $\mathrm{CO}_{2}$ profiles are much more uniform. In the afternoon, the cumulated net uptake by the vegetation reduces the concentration, and daytime mixing transports the air depleted in $\mathrm{CO}_{2}$ higher up. In the evening the $\mathrm{CO}_{2}$ concentration in the lower part of the profiles is further reduced, and on some days $\mathrm{CO}_{2}$ is increasing with height in the ABL when convection has stopped.

REMO is able to reproduce realistically the diurnal variation in the $\mathrm{CO}_{2}$ vertical profiles (Fig. 11). In many cases, however, the reduction of $\mathrm{CO}_{2}$ during the day is not strong enough compared to the measurements. Possible explanations could be that the net uptake of $\mathrm{CO}_{2}$ by the vegetation is underestimated in the model (not so clear from Fig. 3) or that the vertical mixing in the model is too strong. We favour this latter hypothesis, since it can be seen that the sharp gradients across the top of the daytime 
convective ABL cannot be reproduced in REMO. Additional inspection of the virtual potential temperature and humidity profiles with measurements shows that, during days when a clearly defined convective ABL develops in the model (e.g. 28 July in Fyodorovskoye and 9 July in Zotino), the $\mathrm{CO}_{2}$ concentration within the $\mathrm{ABL}$ is strongly reduced by approximately $10 \mathrm{ppmv}$ compared to the atmosphere above. One has to keep in mind that the aircraft profiles reflect in the lower part more local fluxes, whereas the model always represents an average for a $55 \mathrm{~km} \times 55 \mathrm{~km}$ grid box. For a more reliable interpretation of the ability of REMO to simulate the vertical structure of the $\mathrm{CO}_{2}$ concentration, more profiles under different conditions would be needed.

\subsection{Modelled and observed monthly average $\mathrm{CO}_{2}$ gradients among stations}

We compare in Fig. 12 the simulated monthly averaged $\mathrm{CO}_{2}$ mixing with observations. Some stations (Appendix and Fig. 2) are continuous sites, which of- fer an accurate determination of the monthly mean $\mathrm{CO}_{2}$ value within an instrumental error on the order of 0.1 ppmv (ZEP, SCH, HUN, MHD). We do not use here continuous records on short towers of eddy covariance measurements (TVR, ZOT), since those data are not calibrated, although they proved informative to study the variability (section 5.1). Other stations are discrete sampling sites, mainly from NOAA/CMDL, where flasks are collected approximately each week (ICE, STM, BAL, KZD, KZM). Monthly average $\mathrm{CO}_{2}$ is computed in that case from a smoothed fit to the weekly flask data in the GLOBALVIEW$\mathrm{CO}_{2}$ (2001) data product. The error bar in Fig. 12 represents the standard deviation of individual flask data from the fit. Finally, we also have four aircraft sites (ORL, TVR, SYK, ZOT) where flasks are collected every $2-3 \mathrm{wk}$ in the lower troposphere below $3000 \mathrm{~m}$. We computed monthly average $\mathrm{CO}_{2}$ values from aircraft data using the same procedure as for ground flask stations, except that the smoothed-fit curve was obtained using all flask samples between 2000 and $3000 \mathrm{~m}$.

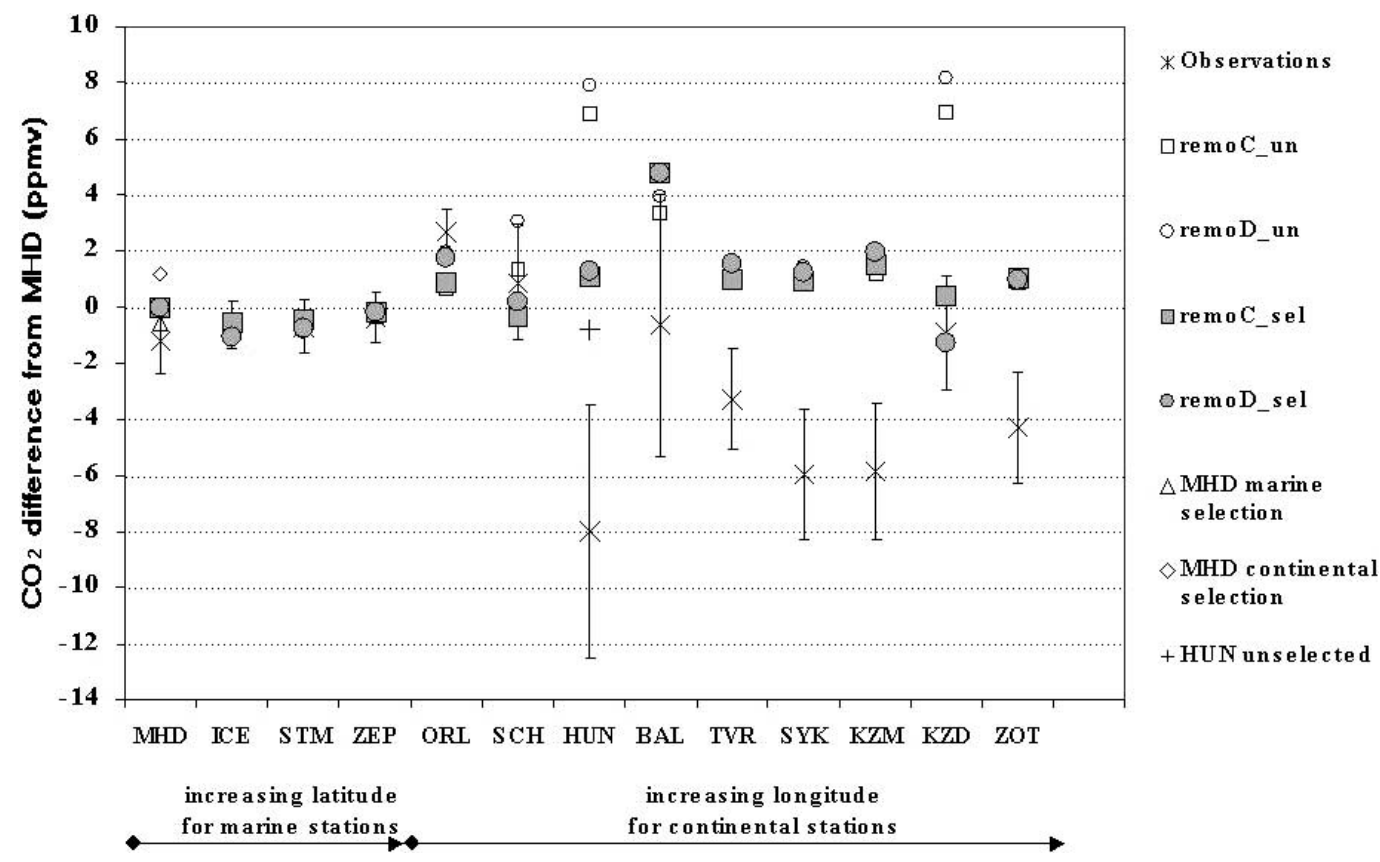

Fig. 12. Mean gradient of $\mathrm{CO}_{2}$ between the North Atlantic ocean and Central Siberia. The first four marine stations are sorted as a function of increasing latitude. The nine remaining continental stations are sorted as a function of eastward increasing longitude. Comparison between observations (crosses with error bars) and REMO selected (respectively unselected) for daytime periods (12:00-14:00 PM LT) is given in filled symbols (respectively open symbols). Simulations using both "forecast" (circles) and "climate" (squares) versions of REMO are presented.

Tellus 54B (2002), 5 
Flask samples both at ground stations and at aircraft sites are collected preferentially during the day, which implies that over continents we must accordingly select the output of models. Aircraft sampling is additionally biased towards fair weather conditions. On the other hand, continuous stations record atmospheric $\mathrm{CO}_{2}$ mixing ratio all day round, and thus are sensitive to night-time accumulation effects over continents. This is illustrated in Fig. 12 at the tall tower HUN by the observed difference of 7.2 ppmv at $115 \mathrm{~m}$ aboveground between the monthly averaged continuous record and the monthly average determined from daytime flask samples. We calculated monthly averaged $\mathrm{CO}_{2}$ mixing ratios from "selected" daytime REMO output (12:00-14:00 LT) as well as from "unselected" output using all time steps.

Figure 12 compares the REMO results with observations. All data and models are arbitrarily referenced against the monthly value of the MHD station, because only $\mathrm{CO}_{2}$ gradients among sites can be predicted by a model. For increasing latitudes over the North Atlantic (Fig. 2), a slight increase in $\mathrm{CO}_{2}$ of 0.87 ppmv is observed between MHD $\left(53^{\circ} \mathrm{N}\right)$ and ZEP $\left(78^{\circ} \mathrm{N}\right)$, which is well captured in all the versions of REMO. Both REMO climate and forecast versions differ from the data by less than $0.5 \mathrm{ppmv}$ in the way they predict the $\mathrm{CO}_{2}$ latitudinal distribution over the ocean. We note also that the selected and unselected REMO output are close to each other over the ocean $(<0.1 \mathrm{ppmv})$ because neither the air-sea fluxes nor the marine boundary layer height have a diurnal variation. Over Western Europe (ORL, SCH) REMO matches the observations within $1 \mathrm{ppmv}$ (ORL, SCH). On the other hand, the composite set of ground stations and aircraft sites shows that there is a large $\mathrm{CO}_{2}$ drop of 6 ppmv between Western Europe and Western Siberia. East of $30^{\circ} \mathrm{E}$, however, all the data come from aircraft sites or mountain stations, with the exception of $\mathrm{KZD}$, so that their $\mathrm{CO}_{2}$ values reflect the attenuation of the summer sink signal with height over Eurasia (e.g. Nakazawa et al., 1997). If we had representative $\mathrm{CO}_{2}$ measurements closer to the ground, their daytime $\mathrm{CO}_{2}$ average value would be even more depleted as compared to ocean stations (Fig. 5). Indeed, the tall tower HUN record shows daytime $\mathrm{CO}_{2}$ values that are 8 ppmv lower than the ocean baseline. REMO does not capture the West to East $\mathrm{CO}_{2}$ drop in the lower troposphere. Since lower troposphere gradients necessarily reflect a large-scale signal, we must search an explanation which involves either an underestimate of the July biospheric sink over Eurasia, or an underesti- mate in the July Northern Hemisphere sink, which is advected into REMO via its boundary conditions provided by TM3. Preliminary simulations with REMO and TURC of a full seasonal cycle of $\mathrm{CO}_{2}$ and fluxes (Chevillard, 2001) suggest that the seasonal phase of NEE in TURC is incorrect, and produces too early a drawdown in spring followed by too rapid a build up in July.

In Figure 12 we observe that the daytime selection of REMO output applied at aircraft sites has no effect, because the diurnal cycle of $\mathrm{CO}_{2}$ becomes attenuated above the boundary layer (Lloyd et al., 2001; Ramonet et al., 2002). In contrast, the daytime selection procedure is critical when matching model calculations and observations near the ground. At HUN, REMO does not reproduces the mean $\mathrm{CO}_{2}$ value, but the difference between unselected and selected model output of 6.5 ppmv is close to the observed one of 7.2 ppmv. A similar effect of model selection is simulated at the ground level flask station KZD. Finally, the differences between the two versions of REMO increase over the interior of the Eurasian continent (up to $2 \mathrm{ppmv}$ ), reflecting differences in meteorology (section 2), but they remain small as compared to the mismatch between model and observations, which we attribute to incorrect biospheric fluxes. As an order of magnitude, we calculate that in order to bring REMO in agreement with the observed drop in $\mathrm{CO}_{2}$, assuming a mean residence time of air of $5 \mathrm{~d}$ within the domain, an extra sink of $0.8 \mathrm{GtC}$ would be needed in July over European Russia and western Siberia. That number translates into a flux of $46 \mathrm{gC} \mathrm{m}^{-2}$ per month, which is about $20 \%$ of the annual primary productivity of western Siberian forests (Schultze et al., 1999). Part of the "missing sink" in REMO comes from the fact that we assumed an annually balanced biospheric flux. By doing so, we ignore the well characterised existence of a terrestrial carbon sink of 0.6-2.3 GtC per year in the Northern Hemisphere (IPCC, 2001) to which uptake in Boreal Asia may contribute as much as $0.5 \pm 0.5 \mathrm{GtC}$ per year (Gurney et al., 2002).

\section{Conclusions}

We simulated the spatial and temporal variations of $\mathrm{CO}_{2}$ over the Eastern part of the North Atlantic, Western Europe and Western Siberia in July 1998 using the regional atmospheric model REMO. The spatial resolution of REMO is at least four times higher than the one of global models commonly used to 
transport $\mathrm{CO}_{2}$, which is desirable to account for the complex geography, meteorology and patterns of carbon sources and sinks in Europe. The variations in $\mathrm{CO}_{2}$ result from atmospheric transport acting on surface fluxes. In this study, high-resolution Net Ecosystem Exchange fluxes predicted by the TURC model using satellite NDVI observations were transported and driven by the simulated meteorology. The simulated hourly Net Ecosystem Exchange compares well with pointwise eddy covariance measurements along an east to west transect in Siberia, European Russia, and Hungary. In particular, the amplitude of the diurnal cycle is correctly reproduced. The simulated $\mathrm{CO}_{2}$ field was compared with atmospheric observations. Firstly, we found that REMO was capable of realistically reproducing the diurnal variation of $\mathrm{CO}_{2}$ near the ground, close to vegetation, which results from the diurnal cycle of NEE being modulated by the diurnal growth of the atmospheric boundary layer. Near industrial regions it was also observed that fossil emissions can contribute to the $\mathrm{CO}_{2}$ diurnal cycle. Secondly, we found that REMO was capable of correctly simulating the diurnal variability of $\mathrm{CO}_{2}$ vertical profiles between the ground and $3000 \mathrm{~m}$, as compared with intensive aircraft campaigns in European Russia and Siberia. Thirdly, using two versions of REMO, we found that a more realistic simulated synoptic meteorology systematically improved the simulation of $\mathrm{CO}_{2}$. In addition, the fine resolution model REMO better reproduced the observations than the coarse resolution model TM3. The above optimistic conclusions, should, however, be tempered by some shortcomings. The monthly $\mathrm{CO}_{2}$ drop of 6 ppmv observed in July 1998 between the North Atlantic Ocean and Western Siberia was totally absent in REMO. This model failure has two origins. Firstly, the geographic and mean seasonal patterns of the biospheric fluxes in TURC are probably incorrect, with part of the disagreement being due to the assumption of annually balanced biospheric fluxes. By doing so, we do not account for the proven existence of a terrestrial carbon sink over northern hemisphere land masses, with at least a fraction of it being located in Boreal Asia. Secondly, above the boundary layer, we found that horizontal $\mathrm{CO}_{2}$ gradients are essentially reflecting the transport of lateral boundary conditions prescribed from TM3. Thus REMO acts merely as an interpolator of TM3 to simulate the mean gradients of $\mathrm{CO}_{2}$ in the troposphere over Eurasia. In the future, simulations of a full seasonal cycle will be performed and compared with flux and atmospheric measurements to evaluate further the performances of our modelling system. This study is a first step towards an integrated model in which the atmospheric and biospheric processes will be directly coupled. This will allow us to account for feedbacks between carbon, water and energy fluxes and atmospheric transport over continental areas. Also, regional inversions of carbon sources and sinks are underway using the REMO model.

\section{Acknowledgements}

We thank all the participants of the EUROSIBERIAN CARBONFLUX project who provided their measurements and valuable advice. Thanks are also due to Zoltan Barcza, Hungary, for providing the measurements of the Hegyhátsál station, and Ralf Podzun, MPI Hamburg, for his helpful technical support concerning the REMO model. The work was funded by the European Commission under contract no. ENV4CT97-0491 (EUROSIBERIAN CARBONFLUX). We thank the ECMWF for providing surface and model level analysis data. We also acknowledge the support of C. Boonne (IPSL's Pole données) for extracting the data.

\section{Appendix: Dataset of atmospheric $\mathrm{CO}_{2}$ measurements}

In this section we compare REMO with observations during July 1998, summarised in Table 5.

\section{A.1. Mace Head, western Ireland (MHD)}

Mace Head is located $5 \mathrm{~m}$ above sea level. Atmospheric $\mathrm{CO}_{2}$ has been continuously measured at Mace Head since June 1992 (Bousquet et al., 1996; Biraud et al., 2000). The meteorological situation is mainly influenced by the westerly passage of frontal systems originating from the North Atlantic Ocean, which determines the $\mathrm{CO}_{2}$ "baseline". Synoptic variations in the origin of air masses, from the North Atlantic or from Europe, induce changes in the $\mathrm{CO}_{2}$ concentration, with large positive and sometimes negative anomalies (Biraud et al., 2000).

\section{A.2. Schauinsland, south Germany (SCH)}

The station is located $10 \mathrm{~km}$ south of Freiburg in the Black Forest on a mountain ridge about $100 \mathrm{~m}$ above the Rhine Valley. It is operated by the German Environment Agency, Berlin, and is part of the Global Atmosphere Watch (GAW) program of the World 
Table 5. Summary description of atmospheric stations used in this study (Appendix)

\begin{tabular}{|c|c|c|c|c|c|}
\hline Station & Code & Location & Altitude (asl) & Sampling & Characteristics \\
\hline Mace Head & MHD & $53^{\circ} \mathrm{N}, 10^{\circ} \mathrm{W}$ & $5 \mathrm{~m}$ & Continuous & Coastal station, Atlantic \\
\hline Schauinsland & $\mathrm{SCH}$ & $48^{\circ} \mathrm{N}, 8^{\circ} \mathrm{E}$ & $1205 \mathrm{~m}$ & Continuous & $\begin{array}{l}\text { Mountain station, } \\
\text { western Europe }\end{array}$ \\
\hline Hegyhátsál & HUN & $46^{\circ} \mathrm{N}, 16^{\circ} \mathrm{E}$ & $248 \mathrm{~m}$ & Continuous & $\begin{array}{l}\text { Tall tower, western } \\
\text { Europe }\end{array}$ \\
\hline Fyodorovskoye & TVR & $56^{\circ} \mathrm{N}, 33^{\circ} \mathrm{E}$ & $\begin{array}{c}265 \mathrm{~m} \\
300-3000 \mathrm{~m}\end{array}$ & $\begin{array}{l}\text { Continuous, } \\
\text { Aircraft }\end{array}$ & $\begin{array}{l}\text { Short tower, } \\
\text { European Russia }\end{array}$ \\
\hline Zotino & ZOT & $60^{\circ} \mathrm{N}, 90^{\circ} \mathrm{E}$ & $\begin{array}{c}100 \mathrm{~m} \\
100-3000 \mathrm{~m}\end{array}$ & $\begin{array}{l}\text { Continuous, } \\
\text { Aircraft }\end{array}$ & $\begin{array}{l}\text { Short tower, central } \\
\quad \text { Siberia }\end{array}$ \\
\hline Baltic sea & BAL & $55^{\circ} \mathrm{N}, 17^{\circ} \mathrm{E}$ & $7 \mathrm{~m}$ & Flask & \\
\hline Orléans & ORL & $48^{\circ} \mathrm{N}, 1^{\circ} \mathrm{E}$ & $100-3000 \mathrm{~m}$ & Aircraft flask & \\
\hline Iceland & ICE & $63^{\circ} \mathrm{N}, 20^{\circ} \mathrm{W}$ & $100 \mathrm{~m}$ & Flask & \\
\hline Kazakstan & KZD & $44^{\circ} \mathrm{N}, 78^{\circ} \mathrm{E}$ & $412 \mathrm{~m}$ & Flask & \\
\hline Kazakstan & KZM & $43^{\circ} \mathrm{N}, 78^{\circ} \mathrm{E}$ & $2519 \mathrm{~m}$ & Flask & \\
\hline Station "M" & STM & $66^{\circ} \mathrm{N}, 2^{\circ} \mathrm{E}$ & $7 \mathrm{~m}$ & Flask & \\
\hline Spitzbergen & ZEP & $79^{\circ} \mathrm{N}, 12^{\circ} \mathrm{E}$ & $474 \mathrm{~m}$ & Flask & \\
\hline
\end{tabular}

Meteorological Organisation. During moderate or strong winds this station is shown to be representative for mean atmospheric $\mathrm{CO}_{2}$ conditions over Western Europe (Schmidt et al., 2001; Schmidt et al., 1996; Levin et al., 1995).

\section{A.3. Fyodorovskoye, European Russia (TVR)}

Fyodorovskoye is located in the Central Forest Reserve, southern taiga, about $300 \mathrm{~km}$ north-west of Moscow. At this station three kinds of $\mathrm{CO}_{2}$ concentration measurements are performed within the EUROSIBERIAN CARBONFLUX project: (1) two short towers of continuous eddy covariance NEE and $\mathrm{CO}_{2}$ above the canopy over a 150 -yr-old spruce forest and over a bog, (2) regular biweekly flask measurements between 200 and $3000 \mathrm{~m}$ and (3) vertical profiles of $\mathrm{CO}_{2}$ during intensive observation periods (Milyukova et al., 2002; Arneth et al., 2002; Ramonet et al., 2002).

\section{A.4. Zotino, central Siberia (ZOT)}

Zotino is located $600 \mathrm{~km}$ north of the city of Krasnoyarsk close to the small village of Zotino, located at the Jenisey river. The region belongs to the north Siberian taiga. Two short towers measure eddy covariance NEE and $\mathrm{CO}_{2}$ concentration above the canopy (Lloyd et al., 2002 and Arneth et al., 2002). Aircraft measurements of $\mathrm{CO}_{2}$ vertical profiles were performed on a regular basis and during intensive observation periods (Lloyd et al., 2002 and Styles et al., 2002).

\section{A.5. Hegyhátsál, western Hungary (HUN)}

Hegyhátsál (Haszpra, 1999; Haszpra et al., 2001; Barcza, 2001) is a tall tower located in a rural site in western Hungary. $\mathrm{CO}_{2}$ vertical profiles are measured along a television transmission tower at 10, 48, 82 and $115 \mathrm{~m}$. NEE has been measured since 1997 by an eddy correlation system placed at $82 \mathrm{~m}$. The surroundings of the tower are covered by different agricultural fields and forest patches.

\section{A.6. Flask sampling sites (MHD, STM, ICE, KZD, $K Z M, B A L, Z E P$ )}

The NOAA CMDL Carbon Cycle Greenhouse Gases group has operated the cooperative air sampling network (http://www.cmdl.noaa.gov/ccgg/ flask/index.html) since 1992. The sites used in this study are given in Table 5 .

\section{REFERENCES}

Ahrens, B., Karstens, U., Rockel, B. and Stuhlmann, R. 1998. On the validation of the atmospheric model REMO with ISCCP data and precipitation measurements using simple statistics. Meteorol. Atmos. Phys. 68, 127-142.
Arneth, A., Kurbatova, J., Kolle, O., Shibistova, O., Lloyd, J., Vygodskaya, N. N. and Schulze, E.-D. 2002. Comparative ecosystem - atmosphere exchange of energy and mass in a European and a central Siberian bog. II. Interseasonal 
and interannual variability of $\mathrm{CO}_{2}$ fluxes. Tellus 54B (this issue).

Barcza, Z. 2001. Long term atmosphere/biosphere exchange of $\mathrm{CO}$ in Hungary. PhD Thesis, Budapest, http://nimbus.elte.hu/ bzoli/thesis/.

Biraud, S., Ciais, P., Ramonet, M., Simmonds, P., Kazan, V., Monfray, P., O'Doherty, S., Spain, T. G. and Jennings, S. G. 2000. European greenhouse gas emissions estimated from continuous atmospheric measurements and radon222 at Mace Head, Ireland. J. Geophys. Res.105, D1,13511366.

Biraud, S., Ciais, P., Ramonet, M., Simmonds, P., Kazan, V., Monfray, P., O'Doherty, S., Spain, T. G. and Jennings, S. G. 2002. Quantification of carbon dioxide, methane, nitrous oxide and chloroform emissions over Ireland from atmospheric observations at Mace Head. Tellus 54, 41-60.

Bousquet, P., Gaudry, A., Ciais, P., Kazan, V., Monfray, P., Simmonds, P. G., Jennings, S. G. and O'Connor, T. C. 1996. Atmospheric $\mathrm{CO}_{2}$ concentration variations recorded at Mace Head, Ireland, from 1992 to 1994. Phys. Chem. Earth 21, 477-481.

Chevillard, A., Ciais, P., Karstens, U., Heimann, M., Schmidt, M., Levin, I., Jacob, D. and Podzun, R. 2002. Transport of ${ }^{222} \mathrm{Rn}$ using the regional model REMO: A detailed comparison with measurements over Europe. Tellus 54B (this issue).

Chevillard, A. 2001. Etude à haute résolution du $\mathrm{CO}_{2}$ atmosphérique en Europe et en Sibérie. Impact pour les bilans de carbone. PhD Thesis, Université Pierre et Marie Curie, Paris, France.

Ciais, P., Tans, P. P., Denning, A. S., Francey, R. J., Trolier, M., Meijer, H. A. J., White, J. W. C., Berry, J. A., Randall, D. A., Collatz, G. J., Sellers, P. J., Monfray, P., and Heimann, M. 1997. A three-dimensional synthesis study of delta O-18 in atmospheric $\mathrm{CO}_{2}$. 2. Simulations with the TM2 transport model. J. Geophys. Res. 102, D5, 58735883.

Conway, T. J., Tans, P. P., Waterman, L. S., Thoning, K., Kitzis, D. R., Masarie, K. A. and Zhang, N. 1994. Evidence for interannual variability of the carbon cycle from the NOAA/CMDL global air sampling network. J. Geophys. Res. 99, D11, 22831-22855.

Denning, A. S., Randall, D. A., Collatz, G. J. and Sellers, P. J. 1996. Simulations of terrestrial carbon metabolism and atmospheric $\mathrm{CO}_{2}$ in a general circulation model. Part 2: Simulated $\mathrm{CO}_{2}$ concentrations. Tellus 48B, 543-567.

Engardt, M. and Holmén, K. 1999. Model simulations of anthropogenic- $\mathrm{CO}_{2}$ transport to an Arctic monitoring station during winter. Tellus 51B, 194-209.

Guerney, K. R., Law, R. M., Denning, S. A., Rayner, P. J., Baker, D. et al. 2002. Towards robust regional estimates of $\mathrm{CO}_{2}$ sources and sinks using atmospheric transport models. Nature 415, 620-630.

GLOBALVIEW- $\mathrm{CO}_{2}$. 2001. Cooperative Atmospheric Data Integration Project - Carbon Dioxide. CD-ROM, NOAA CMDL, Boulder Colorado [also available on Internet via anonymous FTP to ftp.cmdl.noaa.gov, Path: $\mathrm{ccg} / \mathrm{co} 2 /$ GLOBALVIEW].
Hamelbeck, F, Haimberger L. and Hantel, M. 2001. Convection in PIDCAP part I: Evaluating LAM convection. Meteorol. Atmos. Phys. 77, 85-98.

Haszpra, L. 1999. On the representativeness of carbon dioxide measurements. J. Geophys. Res. 104, D21, 2695326960.

Haszpra, L., Barcza, Z., Bakwin, P. S., Berger, B. W., Davis, K. J. and Weidinger, T. 2001. Measuring system for the long-term monitoring of biosphere/atmosphere exchange of carbon dioxide. J. Geophys. Res. 106, D3, 3057-3069.

Heimann, M. 1995. The global tracer model TM2,. Technical Report No.10, Deutsches Klima Rechenzentrum, Hamburg, 47 pp.

Hollmann, R., Mueller, J. and Stuhlmann, R. 2000. A regional earth radiation budget derived with $\mathrm{ScaRaB}$ for validation purposes in BALTEX. Phys. Chem. Earth B 25, 69-72.

IPCC 2001.

Jacob, D. and Podzun, R. 1997. Sensitivity studies with the regional climate model REMO. Meteorol. Atmos. Phys. 63, 119-129.

Jacob, D., Van den Hurk, B. J. J. M., Andrae, U., Elgered, G., Fortelius, C., Graham, L. P., Jackson, S. D., Karstens, U., Köpken, C., Lindau, R., Podzun, R., Rockel, B., Rubel, F., Sass, B. H., Smith, R. N. B., and Yang, X. 2001. A comprehensive model inter-comparison study investigating the water budget during the BALTEX-PIDCAP period. Meteorol. Atmos. Phys. 77, 19-43.

Jürrens, R. 1999. Validation of surface fluxes in climate simulations of the Arctic with the regional model REMO. Tellus 51A, 698-709.

Karstens, U., Nolte-Holube, R. and Rockel, B. 1996. Calculation of the Water Budget over the Baltic Sea Catchment Area using the Regional Forecast Model REMO for June 1993. Tellus 48A, 684-692.

Kjellström, E., Holmén, K., Eneroth, K. and Engardt, M. 2002. Summertime Siberian $\mathrm{CO}_{2}$ simulations with the regional transport model MATCH: A feasibility study of carbon uptake calculations from EUROSIB data. Tellus, 54B (this issue).

Lafont, S., Kergoat, L., Dedieu, G., Chevillard, A., Kjellström, E., Karstens, U. and Kolle, O. 2002. Spatial and temporal variability of land $\mathrm{CO}_{2}$ fluxes estimated with remote sensing and analysis data over western Eurasia. Tellus 54B (this issue).

Langmann, B. 2000. Numerical modelling of regional scale transport and photochemistry directly together with meteorological processes. Atmos. Environ. 34, 3585-3598.

Langmann, B. and Bauer, S. 2002. On the importance of reliable background concentrations of ozone for regional scale photochemical modelling. J. Atmos. Chem., in press.

Levin, I., Graul, R. and Trivett, N. B. A. 1995. Long-term observations of atmospheric $\mathrm{CO}_{2}$ and carbon isotopes at continental sites in Germany. Tellus 47B, 23-34.

Lindau, R. and Ruprecht, E. 2000. SSM/I-derived total water vapour content over the Baltic Sea compared to independent data. Meteorol. Z. 9, 117-123.

Lloyd, J., Langenfelds, R., Francey, R. J., Gloor, M., Zolothukine, D., Tchebakova, N. M., Shibistova, O., 
Allison, C. A., Brand, W. A., Werner, R. and Schulze, E.-D. 2002. A trace gas climatology above Zotino, central Siberia. Tellus 54B (this issue).

Lloyd, J., Francey, R. J., Mollicone, D., Raupach, M. R., Sogachev, A., Arneth, A., Byers, J. N., Kelliher, F. M., Rebmann, C., Valentini, R., Wong, S.-C., Bauer, G. and Schulze, E.-D. 2001. Vertical profiles, boundary layer budgets and regional flux estimates for $\mathrm{CO}_{2}$ and its ${ }^{13} \mathrm{C} /{ }^{12} \mathrm{C}$ ratio for water vapor above a forest/bog mosaic in central Siberia. Global Biogeochem. Cycles 15, 267-284.

Louis, J.-F. 1979. A parametric model of vertical eddy fluxes in the atmosphere. Bound. Layer Meteor. 17, 187-202.

Majewski, D. 1991. The Europamodell of the Deutscher Wetterdienst., ECMWF course "Numerical methods in atmospheric models", 2, 147-191.

Marland, G., Boden, T. A. and Andres, R. J. 2000. Global, Regional, and National $\mathrm{CO}_{2}$ Emissions. In: Trends: a compendium of data on global change. Carbon Dioxide Information Analysis Center, Oak Ridge National Laboratory U.S. Department of Energy, Oak Ridge, Tenn., USA.

Mellor, B. and Yamada, T. 1974. A hierarchy of turbulence closure models for planetary boundary layers. J. Atmos. Sci. 31, 1791-1806.

Milyukova, I., Kolle, O., Varlagin, A., Vygodskoya, N. N., Schulze, E.-D. and Lloyd, J. 2002. Carbon balance of a southern taiga spruce stand in European Russia. Tellus 54B (this issue).

Nakazawa, T., Sugawara, S., Inoue, G., Machida, T., Makshyutov, and Mukai, H. 1997. Aircraft measurements of the concentrations of $\mathrm{CO}_{2}, \mathrm{CH}_{4}, \mathrm{~N}_{2} \mathrm{O}$ and $\mathrm{CO}$ and the carbon and oxygen isotopic ratios of $\mathrm{CO}_{2}$ in the troposphere over Russia. J. Geophys. Res. 102, (D3), 3843-3859.

Olivier, J. G. J., Bouwman, A. F., Van der Maas, C. W. M., Berdowski, J. J. M., Veldt, C., Bloos, J. P. J., Visschedijk, A. J. H., Zandyelt, P. Y. J. and Haverlag, J. L. 1996. Description of EDGAR Version 2.0. A set of global emission inventories of greenhouse gases and ozone-depleting substances for all anthropogenic and most natural sources on a per country basis and on $1 \times 1$ grid. RIVM/TNO report, December 1996. RIVM, Bilthoven, RIVM report nr. 771060 002. [TNO MEP report nr. R96/119].

Ramonet, M., Ciais, P., Nepomniachii, I., Sidorov, K., Neubert, R. E. M., Picard, D., Kazan, V., Biraud, S., Gusti, M., Kolle, O., Schulze, E.-D. and Lloyd, J. 2002. Three years of aircraft based trace gas measurements over the Fyodoroskoye southern taiga forest, $300 \mathrm{~km}$ North-West of Moscow. Tellus 54B (this issue).

Rockel, B. and Karstens, U. 2001. Development of the water budget for three extra-tropical cyclones with intense rainfall over Europe. Meteorol. Atmos. Phys. 77, 75-83.

Roeckner, E., Arpe, K., Bengtsson, L., Christoph, M., Claussen, M., Duemenil, L., Esch, M., Giorgetta, M., Schlese, U. and Schulzweida, U. 1996. The atmospheric general circulation model ECHAM-4: Model description and simulation of present-day climate. MPI, Hamburg, Germany.
Ruimy, A., Dedieu, G. and Saugier, B. 1996. TURC: a diagnostic model of continental gross primary productivity as net primary productivity, Global Biogeochem. Cycles $\mathbf{1 0}$, 269-285.

Schmidt, M., Graul, R., Sartorius, H. and Levin, I. 1996. Carbon dioxide and methane in continental Europe: A climatology, and ${ }^{222}$ radon-based emission estimates. Tellus 48B, 457-473.

Schmidt, M., Glatzel-Mattheier, H., Sartorius, H., Worthy, D. E. and Levin, I. 2001. Western European $\mathrm{N}_{2} \mathrm{O}$ emissions: A top-down approach based on atmospheric observations. J. Geophys. Res. 106, D6, 5507-5516.

Schrodin, R. 1993 (ed.): Quaterly report of the Operational NWP-Models of the Deutscher Wetterdienst. Available from the Deutscher Wetterdienst, Offenbach, Gernany.

Schultze, E.-D., Lloyd, J., Kelliher, F. M., Wirth, C., Rebmann, C., Lühker, B., Mund, M., Knohl, A., Milykova, I., Schulze, W., Ziegler, W., Varlagin, A., Valentini, R., Sogachov, A., Valentini, R., Dore, S., Grigoriev, S., Kolle, O., Tchebakova, N., Vgodskaya, N. N. 1999. Productivity of forests in the Eurosiberian boreal region and their potential to act as a carbon sink - A synthesis. Global Change Biology 5, 703722 .

Smolarkiewicz, P. K. 1983. A simple positive definite advection scheme with small implicit diffusion. Mon. Wea. Rev. 111, 479-486.

Styles, J. M., Lloyd, J., Zolothukine, D., Lawton, K. A., Tchebakova, N., Francey, R. J., Arneth, A., Salamakho, D., Kolle, O. and Schulze, E.-D. 2002. Estimates of regional surface $\mathrm{CO}_{2}$ exchange and carbon and oxygen isotope discrimination during photosynthesis from concentration profiles in the atmospheric boundary layer. Tellus , 54B (this issue).

Stull, R. B. 1988. An introduction to boundary layer meteorology. Kluwer Academic Publishers, Dordrecht, The Netherlands.

Takahashi, T., Sutherland, S. C., Sweeney, C., Poisson, A., Metzel, N., Tilbrook, B., Bates, N., Wanninkof, R., Feely, R. A., Sabine, C., Olafsson, J. and Nojiri, Y. 2002. Global sea-air $\mathrm{CO}_{2}$ flux based on climatological surface ocean $\mathrm{pCO}_{2}$, and seasonal biological and temperature effects. Deep-sea Res. 1008 (in press).

Tiedtke, M. 1989. A comprehensive mass flux scheme for cumulus parameterization in large scale models. Mon. Wea. Rev. 117, 1779-1800.

van Meijgaard, E., Andrae, U. and Rockel, B. 2001. Comparison of model predicted cloud parameters and surface radiative fluxes with observations on the $100 \mathrm{~km}$ scale. Meteorol. Atmos. Phys. 77, 109-130.

Wanninkhof, R. 1992. Relationship between wind speed and gas exchange. J. Geophys. Res. 97, 7373-7382.

Zhang, Y., Rockel, B., Stuhlmann, R., Hollmann, R. and Karstens, U. 2001. REMO cloud modeling: Improvements and validation with ISCCP DX data. J. Appl. Meteorol. 40, 389-408. 